\title{
An Assessment of ERA5 Reanalysis for Antarctic Near-Surface Air Temperature
}

\author{
Jiangping Zhu ${ }^{1,2} \mathbb{D}^{-}$, Aihong Xie ${ }^{1, *}$, Xiang Qin ${ }^{1, *}$, Yetang Wang ${ }^{3 \oplus}$, Bing $\mathrm{Xu}^{1,2}$ and Yicheng Wang 4 \\ 1 State Key Laboratory of Cryospheric Sciences, Northwest Institute of Eco-Environment and Resources, \\ Chinese Academy of Sciences, Lanzhou 730000, China; zhujiangping@nieer.ac.cn (J.Z.); \\ xubing19@mails.ucas.ac.cn (B.X.) \\ 2 University of Chinese Academy of Sciences, Beijing 100049, China \\ 3 College of Geography and Environment, Shandong Normal University, Jinan 250014, China; \\ yetangwang@sdnu.edu.cn \\ 4 Lanzhou Central Meteorological Observatory, Lanzhou 730000, China; wangyicheng_climate@outlook.com \\ * Correspondence: xieaihong@nieer.ac.cn or xieaih@lzb.ac.cn (A.X.); qinxiang@lzb.ac.cn (X.Q.); \\ Tel.: +86-0931-4967338 (A.X.); +86-0931-8278034 (X.Q.)
}

check for

updates

Citation: Zhu, J.; Xie, A.; Qin, X.; Wang, Y.; Xu, B.; Wang, Y. An Assessment of ERA5 Reanalysis for Antarctic Near-Surface Air Temperature. Atmosphere 2021, 12, 217. https://doi.org/10.3390/ atmos12020217

Received: 23 December 2020

Accepted: 28 January 2021

Published: 5 February 2021

Publisher's Note: MDPI stays neutral with regard to jurisdictional claims in published maps and institutional affiliations.

Copyright: (c) 2021 by the authors. Licensee MDPI, Basel, Switzerland. This article is an open access article distributed under the terms and conditions of the Creative Commons Attribution (CC BY) license (https:// creativecommons.org/licenses/by/ $4.0 /)$.

\begin{abstract}
The European Center for Medium-Range Weather Forecasts (ECMWF) released its latest reanalysis dataset named ERA5 in 2017. To assess the performance of ERA5 in Antarctica, we compare the near-surface temperature data from ERA5 and ERA-Interim with the measured data from 41 weather stations. ERA5 has a strong linear relationship with monthly observations, and the statistical significant correlation coefficients $(p<0.05)$ are higher than 0.95 at all stations selected. The performance of ERA5 shows regional differences, and the correlations are high in West Antarctica and low in East Antarctica. Compared with ERA5, ERA-Interim has a slightly higher linear relationship with observations in the Antarctic Peninsula. ERA5 agrees well with the temperature observations in austral spring, with significant correlation coefficients higher than 0.90 and bias lower than $0.70{ }^{\circ} \mathrm{C}$. The temperature trend from ERA5 is consistent with that from observations, in which a cooling trend dominates East Antarctica and West Antarctica, while a warming trend exists in the Antarctic Peninsula except during austral summer. Generally, ERA5 can effectively represent the temperature changes in Antarctica and its three subregions. Although ERA5 has bias, ERA5 can play an important role as a powerful tool to explore the climate change in Antarctica with sparse in situ observations.
\end{abstract}

Keywords: ERA5; ERA-Interim; Antarctica; air temperature; in situ observations

\section{Introduction}

Antarctica, the southernmost continent on earth, plays a central role in the global climate system [1-3]. Many studies have explored climate change in Antarctica [4-8] and its influence, including melting of the Antarctic ice sheet and subsequent sea level rise [9]. The temperature increase is an important reason for the melting of the ice sheet [10]. However, the temperature variability in Antarctica is still not obvious compared with the warming trend of global average temperature [11]. For instance, the Antarctic Peninsula is well known to be one of the most rapidly warming regions across the Antarctic continent [12], but this trend has been absent since 1998 [13]. West Antarctica is the key region for heat and moisture in Antarctica, and it shows a significant warming trend, while there is no significant temperature change in East Antarctica [14,15]. In Antarctica, long-term observational datasets are scarce, and most weather stations are located at coastal areas [16] (Figure 1), which limits climate research in Antarctica. 


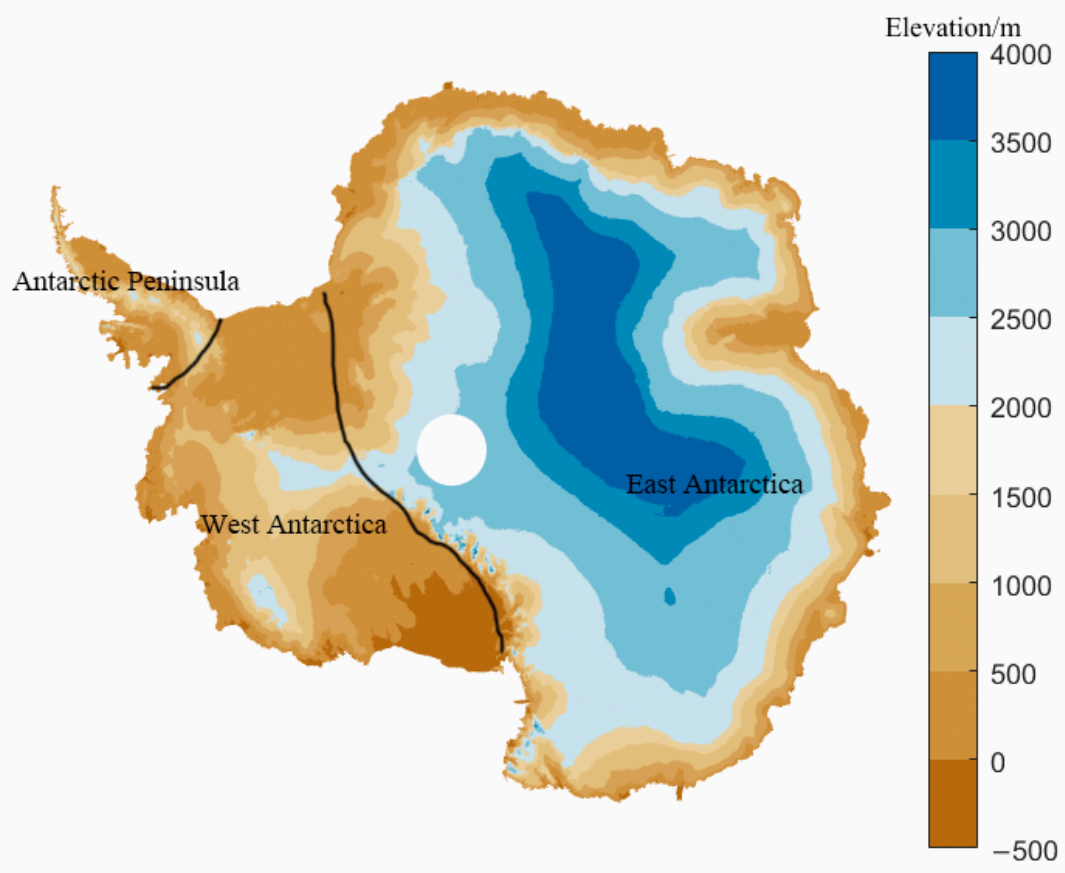

(a)

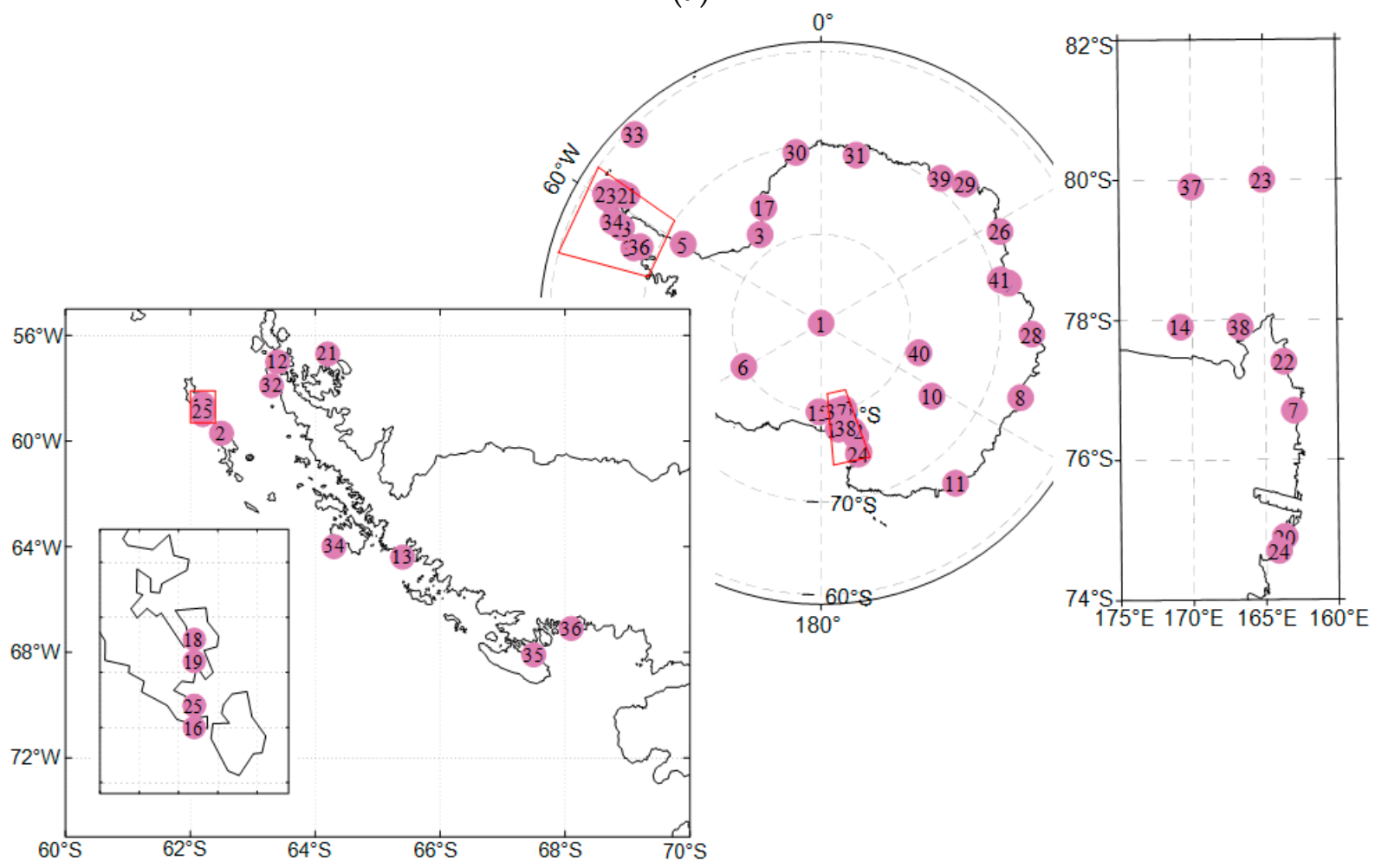

(b)

Figure 1. (a) Map of Antarctica and the thick black lines outline the boundaries of the three main Antarctic regions; (b) Spatial distribution of 41 stations cited in the text. Note that the numbers refer to the lists in Table 1. 
Table 1. List of the selected meteorological stations including station names, latitude, longitude, elevation, and record lengths.

\begin{tabular}{|c|c|c|c|c|c|c|}
\hline Number & Station Names & Latitude & Longitude & Elevation (m) & Record Lengths & Manual or AWS \\
\hline 1 & Amundsen-Scott & $90 S$ & $\mathrm{OE}$ & 2835 & 1979-2018 & Manual \\
\hline 2 & Arturo Prat & $62.5 S$ & $59.7 \mathrm{~W}$ & 5 & 1979-2018 & Manual \\
\hline 3 & Belgrano II & 77.9S & $34.6 \mathrm{~W}$ & 256 & 1980-2018 & Manual \\
\hline 4 & Bellingshausen & $62.2 S$ & $58.9 \mathrm{~W}$ & 16 & $1979-2018$ & Manual \\
\hline 5 & Butler Island & $72.2 \mathrm{~S}$ & $60.2 \mathrm{~W}$ & 91 & 1986-2018 & AWS \\
\hline 6 & Byrd & $80.0 \mathrm{~S}$ & $119.4 W$ & 1515 & 1980-2018 & Manual \\
\hline 7 & Cape Ross & $76.7 \mathrm{~S}$ & $163.0 \mathrm{E}$ & 201 & 1990-2018 & AWS \\
\hline 8 & Casey & $66.3 S$ & $110.5 \mathrm{E}$ & 42 & 1979-2018 & Manual \\
\hline 9 & Davis & $68.6 \mathrm{~S}$ & $78.0 \mathrm{E}$ & 13 & 1979-2018 & Manual \\
\hline 10 & Dome C II & $75.1 S$ & $123.4 \mathrm{E}$ & 3280 & 1995-2018 & AWS \\
\hline 11 & Dumont d'Urville & $66.7 \mathrm{~S}$ & $140.0 \mathrm{E}$ & 43 & $1979-2018$ & Manual \\
\hline 12 & Esperanza & $63.4 S$ & $57.0 \mathrm{~W}$ & 13 & 1979-2018 & Manual \\
\hline 13 & Faraday & $65.4 \mathrm{~S}$ & $64.4 \mathrm{~W}$ & 11 & 1979-2018 & Manual \\
\hline 14 & Ferrell & $77.9 \mathrm{~S}$ & $170.8 \mathrm{E}$ & 45 & $1980-2018$ & AWS \\
\hline 15 & Gill & $80.0 \mathrm{~S}$ & $178.6 \mathrm{~W}$ & 30 & 1985-2018 & AWS \\
\hline 16 & Great Wall & $62.2 S$ & $59.0 \mathrm{~W}$ & 10 & 1985-2018 & Manual \\
\hline 17 & Halley & $75.5 S$ & $26.4 \mathrm{~W}$ & 30 & 1979-2018 & Manual \\
\hline 18 & Jubany & $62.2 \mathrm{~S}$ & $58.6 \mathrm{~W}$ & 4 & 1985-2019 & Manual \\
\hline 19 & King Sejong & $62.2 \mathrm{~S}$ & $58.7 \mathrm{~W}$ & 11 & 1988-2018 & Manual \\
\hline 20 & Manuela & $74.9 S$ & 163.7E & 80 & 1984-2018 & AWS \\
\hline 21 & Marambio & $64.2 S$ & $56.7 \mathrm{~W}$ & 198 & 1979-2018 & Manual \\
\hline 22 & Marble Point & $77.4 \mathrm{~S}$ & 163.7E & 120 & 1980-2018 & AWS \\
\hline 23 & Marilyn & $80.0 \mathrm{~S}$ & $165.1 \mathrm{E}$ & 75 & $1987-2018$ & AWS \\
\hline 24 & Mario Zucchelli & $74.7 \mathrm{~S}$ & $164.1 \mathrm{E}$ & 92 & $1987-2018$ & Manual \\
\hline 25 & Marsh & $62.2 \mathrm{~S}$ & $58.9 \mathrm{~W}$ & 10 & 1979-2018 & Manual \\
\hline 26 & Mawson & $67.6 \mathrm{~S}$ & $62.9 \mathrm{E}$ & 16 & 1979-2018 & Manual \\
\hline 27 & McMurdo & $77.9 \mathrm{~S}$ & $166.7 \mathrm{E}$ & 24 & 1979-2018 & Manual \\
\hline 28 & Mirny & $66.5 \mathrm{~S}$ & $93.0 \mathrm{E}$ & 30 & 1979-2018 & Manual \\
\hline 29 & Molodeznaja & $67.7 \mathrm{~S}$ & $45.9 \mathrm{E}$ & 40 & $1979-2018$ & Manual \\
\hline 30 & Neumayer & $70.7 \mathrm{~S}$ & $8.4 \mathrm{~W}$ & 50 & 1981-2018 & Manual \\
\hline 31 & Novolazarevskaya & $70.8 \mathrm{~S}$ & $11.8 \mathrm{E}$ & 119 & 1979-2018 & Manual \\
\hline 32 & O'Higgins & $63.3 S$ & $57.9 \mathrm{~W}$ & 10 & 1979-2018 & Manual \\
\hline 33 & Orcadas & $60.7 \mathrm{~S}$ & $44.7 \mathrm{~W}$ & 6 & 1979-2018 & Manual \\
\hline 34 & Palmer & $64.3 S$ & $64.0 \mathrm{~W}$ & 8 & 1979-2018 & Manual \\
\hline 35 & Rothera & $67.5 \mathrm{~S}$ & $68.1 \mathrm{~W}$ & 32 & 1979-2018 & Manual \\
\hline 36 & San Martin & $68.1 S$ & $67.1 \mathrm{~W}$ & 4 & $1979-2018$ & Manual \\
\hline 37 & Schwerdtfeger & $79.9 S$ & $170.0 \mathrm{E}$ & 60 & 1985-2018 & AWS \\
\hline 38 & Scott Base & $77.9 \mathrm{~S}$ & $166.7 \mathrm{E}$ & 16 & 1979-2018 & Manual \\
\hline 39 & Syowa & $69.0 \mathrm{~S}$ & $39.6 \mathrm{E}$ & 21 & 1979-2018 & Manual \\
\hline 40 & Vostok & $78.5 S$ & $106.9 \mathrm{E}$ & 3490 & 1979-2018 & Manual \\
\hline 41 & Zhongshan & $69.4 S$ & $76.4 \mathrm{E}$ & 18 & 1989-2018 & Manual \\
\hline
\end{tabular}

AWS, automatic weather station.

Reanalysis datasets can provide a numerical description of the recent climate and describe complete and multivariate atmospheric conditions by combining a fixed data assimilation system with global observations and satellite data $[2,17,18]$. Over the past decades, reanalysis products have been widely used in many research fields, especially in areas with sparse observations [19-21]. At present, a number of available global reanalyses have been released by China [22], Europe [18], the United States [23], and Japan [24]. Many studies have assessed the performance of these datasets in different regions [25-28]. Although the estimation for ERA-Interim shows that the largest differences are found in the polar regions, particularly in Antarctica, where this reanalysis dataset differs to the greatest extent in terms of both absolute temperatures and anomalies from measured near-surface air temperatures $[29,30]$, some studies have generally found that ERA-Interim performs well in representing Antarctic temperature [31-33]. ERA5 is the latest atmospheric reanalysis produced by the European Center for Medium-Range Weather Forecasts (ECMWF). As 
the fifth generation of ECMWF reanalysis, ERA5 contains most of the parameters available in ERA-Interim, and it has many innovative features. The ERA-Interim dataset is at a 0.7 degree resolution and ERA5 provides a much higher resolution of 0.25 degree [34]. An assessment of ERA5 in the southern Antarctic Peninsula-Ellsworth Land Region, with a specific focus on its application for ice core data, has been performed [34], while no research paper has assessed the applicability of ERA5 for Antarctic near-surface temperature. Therefore, our objective is to assess the performance of ERA5 in terms of Antarctic near-surface air temperature and to investigate whether ERA5 is a useful reanalysis for future research and model development in Antarctica.

\section{Materials and Methods}

More than 100 automatic weather stations (AWSs) have been installed in Antarctica to measure basic meteorological parameters [16,35]. For the AWS data, there are three important issues: (1) most AWSs fail to produce complete and accurate data for the harsh environment in Antarctica; (2) many AWSs have moved short distances from their original location, even several times, during their operation period; and (3) because snow accumulates on the surface, the height of some AWSs above the ground slightly changes, which normally results in slightly lower temperature readings $[31,35,36]$. For these reasons, the project called the Reference Antarctic Data for Environmental Research (READER) was undertaken by the Scientific Committee on Antarctic Research (SCAR). The observational data we used were collected by 9 AWSs and 32 manual stations. The data we used in the present study were all from the READER project and cover at least 20 years. Locations of the manned stations and the AWSs are shown in Figure 1, and we provide detailed information on the compared observations in Table 1. Observational data can be downloaded at https:/ /legacy.bas.ac.uk/met/READER/surface [37]. The ice sheet mask in Figure 1 is derived from the Antarctic Digital Database (ADD), available at http:/ / www.add.scar.org/ index.jsp [38].

ERA5 reanalysis, as a part of the implementation of the EU-funded Copernicus Climate Change Service, uses the Cycle 41r2 Integrated Forecasting System (IFS) and provides data on the global weather and climate. Both ERA5 and ERA-Interim are produced by the ECMWF and use a four-dimensional variational assimilation system. Compared with ERA-Interim, ERA5 benefits from many improvements in the observation operators as well as a decade of developments in model physics, core dynamics, and data assimilation. Thus, ERA5 replaces the highly successful ERA-Interim reanalysis, which provides data from 1 January 1979 to 31 August 2019. Similarly, ERA5 reanalysis extends to 1 January 1950, and it provides hourly data on many atmospheric, land surface, and sea state parameters together with estimates of uncertainty for the first time. Compared with ERA-Interim, ERA5 has a number of new features: (1) the significantly enhanced horizontal resolution is a $31 \mathrm{~km}$ grid spacing in ERA 5 but $79 \mathrm{~km}$ in ERA-Interim; (2) for radiance data, ERA5 uses version 11 of the Radiative Transfer for the TIROS Operational Vertical Sounder (RTTOV-11) as the observation operator and an all-sky approach instead of the RTTOV-7 and clear-sky approach in ERA-Interim; (3) the number of observations assimilated in ERA5 has increased remarkable relative to ERA-Interim; (4) ERA5 contains hourly output throughout and an uncertainty estimate of $63 \mathrm{~km}$ grid spacing; (5) ERA5 includes forcings for total solar irradiance, ozone, greenhouse gases, and some aerosols; and (6) ERA5 parameters are accumulated from previous post-processing, whereas those in ERA-Interim are accumulated from the beginning of the forecast $[39,40]$.

ERA5 data are available free on the following web interface: https:/ / cds.climate. copernicus.eu/\#! / search?text=ERA5\&type=dataset [41]. ERA-Interim data can be downloaded at https: / / apps.ecmwf.int/datasets / data/interim-full-daily /levtype=sfc/ [42].

Because the deviation between the grid and actual elevation can introduce temperature biases in the reanalyses, we adjust the temperature of the reanalysis grid box over the stations using the temperature environmental vertical lapse rate of $6.5^{\circ} \mathrm{C} \mathrm{km}^{-1}$ that is the average vertical decline rate of air temperature in the troposphere [16]. 
To compare the measured temperature with ERA reanalyses, it is necessary to extract the monthly temperature from reanalyses, and we take the nearest grid data as the comparative data instead of interpolating the data to where the stations located for different interpolation methods may introduce errors caused by assumptions. We selected the correlation coefficient (R), mean bias (MB), and the ratio of the standard deviations (RSD) as indicators to examine the performance of ERA5 and ERA-Interim for Antarctic near-surface temperature. Parameter calculations are executed only for the overlapping time spans. The significance of the correlations is determined by the standard $\mathrm{t}$ test, and $\mathrm{F}$ test is used to estimate the significance of trends, and the significant is at the $95 \%$ confidence interval.

\section{Results}

\subsection{The Performance of ERA5 over Antarctica}

The correlation coefficients between ERA5 and observations are significant for all months, and they are higher than 0.82, and those of ERA-Interim are more than 0.84, indicating a stronger linear relationship of monthly temperature. Figure 2 displays the MB between the monthly mean air temperature measured at the 41 weather stations and the ECMWF reanalysis output data, and we also plot the RSD in this figure. For ERA5, warm bias prevails between May and September. ERA5 has a monthly bias between -0.44 and $1.19^{\circ} \mathrm{C}$, and the extreme values appear in August and December, respectively. ERA-Interim has a cold bias in all months, and this characteristic is different from that of ERA5. In particular, a large contrast in ERA5 and ERA-Interim bias occurs in winter (June-August (JJA)).
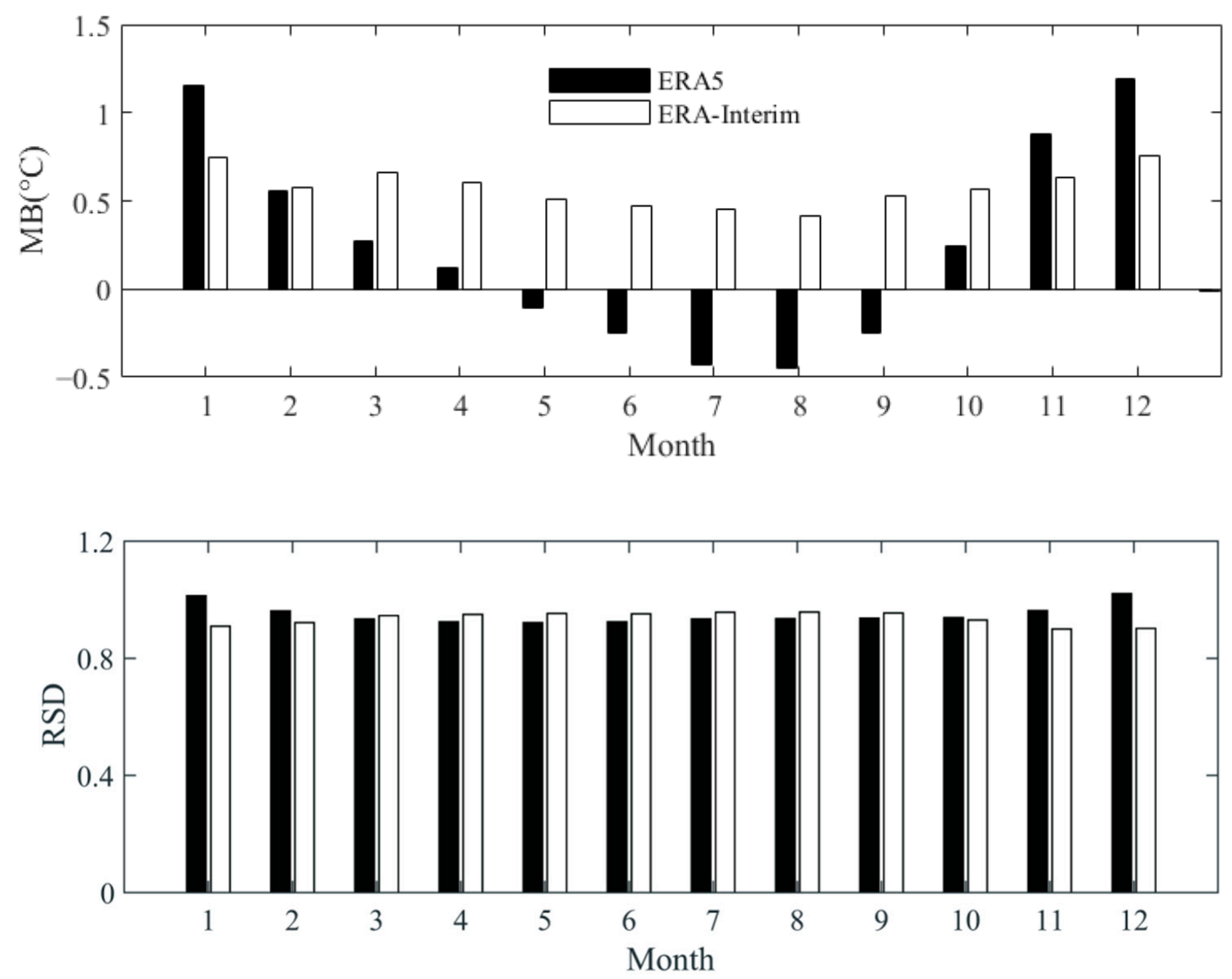

Figure 2. Mean bias $\left(\mathrm{MB},{ }^{\circ} \mathrm{C}\right)$ and ratio of standard deviations (RSD) of monthly near-surface temperature simulation from ERA5 and ERA-Interim. 
As shown in Table 2, for the whole Antarctic ice sheet, there are significant correlations between ERA5 and observations for all annual and seasonal temperature. Compared to ERA-Interim, ERA5 exhibits lower performance only in summer (December-February (DJF)). In this season, the significant correlation coefficient of ERA5 is 0.84 , and the corresponding value of ERA-Interim is 0.86 . Table 3 shows the bias between ERA reanalyses and observations. In general, ERA5 performs worst in summer, with the largest bias of $1.06{ }^{\circ} \mathrm{C}$ and the lowest correlation coefficient. Over the whole of Antarctica, ERA5 has good performance in autumn (March-May (MAM)) and spring (September-November $(\mathrm{SON})$ ), with low bias of 0.16 and $0.38{ }^{\circ} \mathrm{C}$, and the highest significant correlation coefficients are 0.90 and 0.93 , respectively. Different from the lowest bias for ERA5, which occurs in MAM, ERA-Interim has the lowest bias of $0.52^{\circ} \mathrm{C}$ in JJA. The greatest bias between ERA reanalyses and observations is shown in DJF, with the cold bias of 1.06 and $0.76{ }^{\circ} \mathrm{C}$ for ERA5 and ERA-Interim, respectively. In Antarctica, a cold bias prevails for annual and seasonal mean temperatures in ERA-Interim, whereas ERA5 shows a warm bias in JJA, when the largest difference between ERA reanalyses is captured. Figure 3 shows the time series of the annual and seasonal mean temperature anomalies with respect to the 1979-2018 mean from 41 observation locations and the corresponding value of ERA reanalyses. Generally, there are no clear anomaly differences between ERA5 and ERA-Interim in Antarctica. ERA reanalyses can reflect common interannual variability, and they can capture the abrupt changes occurring in Antarctica.

Table 2. Correlation between observations and ERA reanalyses for annual, autumn (MAM), winter (JJA), spring (SON), and summer (DJF) mean temperatures in Antarctica, East Antarctica, West Antarctica, and the Antarctic Peninsula.

\begin{tabular}{cccccc}
\hline & Antarctica & $\begin{array}{c}\text { East } \\
\text { Antarctica }\end{array}$ & $\begin{array}{c}\text { West } \\
\text { Antarctica }\end{array}$ & $\begin{array}{c}\text { Antarctic } \\
\text { Peninsula }\end{array}$ \\
\hline \multirow{2}{*}{ Annual } & ERA5 & 0.92 & 0.89 & 0.93 & 0.94 \\
& ERA-Interim & 0.91 & 0.88 & 0.91 & 0.96 \\
MAM & ERA5 & 0.90 & 0.88 & 0.93 & 0.92 \\
& ERA-Interim & 0.90 & 0.88 & 0.90 & 0.93 \\
JJA & ERA5 & 0.92 & 0.91 & 0.93 & 0.92 \\
& ERA-Interim & 0.91 & 0.90 & 0.88 & 0.94 \\
SON & ERA5 & 0.93 & 0.91 & 0.97 & 0.93 \\
& ERA-Interim & 0.93 & 0.91 & 0.96 & 0.95 \\
DJF & ERA5 & 0.84 & 0.85 & 0.89 & 0.82 \\
& ERA-Interim & 0.86 & 0.87 & 0.88 & 0.83 \\
\hline
\end{tabular}

Note: The correlation coefficients are all significant at the $95 \%$ confidence interval.

Table 3. Bias $\left({ }^{\circ} \mathrm{C}\right)$ between ERA reanalyses and observations for annual, autumn (MAM), winter (JJA), spring (SON), and summer (DJF) mean temperature in Antarctica, East Antarctica, West Antarctica, and the Antarctic Peninsula.

\begin{tabular}{cccccc}
\hline & Antarctica & $\begin{array}{c}\text { East } \\
\text { Antarctica }\end{array}$ & $\begin{array}{c}\text { West } \\
\text { Antarctica }\end{array}$ & $\begin{array}{c}\text { Antarctic } \\
\text { Peninsula }\end{array}$ \\
\hline \multirow{2}{*}{ Annual } & ERA5 & 0.34 & 0.51 & -0.66 & 0.58 \\
& ERA-Interim & 0.64 & 0.97 & 0.03 & 0.23 \\
MAM & ERA5 & 0.16 & 0.07 & -0.77 & 0.67 \\
& ERA-Interim & 0.64 & 0.93 & 0.20 & 0.15 \\
JJA & ERA5 & -0.28 & -0.22 & -1.25 & 0.10 \\
& ERA-Interim & 0.52 & 0.74 & 0.17 & -0.04 \\
SON & ERA5 & 0.38 & 0.59 & -0.69 & 0.63 \\
& ERA-Interim & 0.63 & 0.96 & -0.06 & 0.33 \\
DJF & ERA5 & 1.06 & 1.53 & -0.01 & 0.96 \\
& ERA-Interim & 0.76 & 1.25 & -0.20 & 0.53 \\
\hline
\end{tabular}




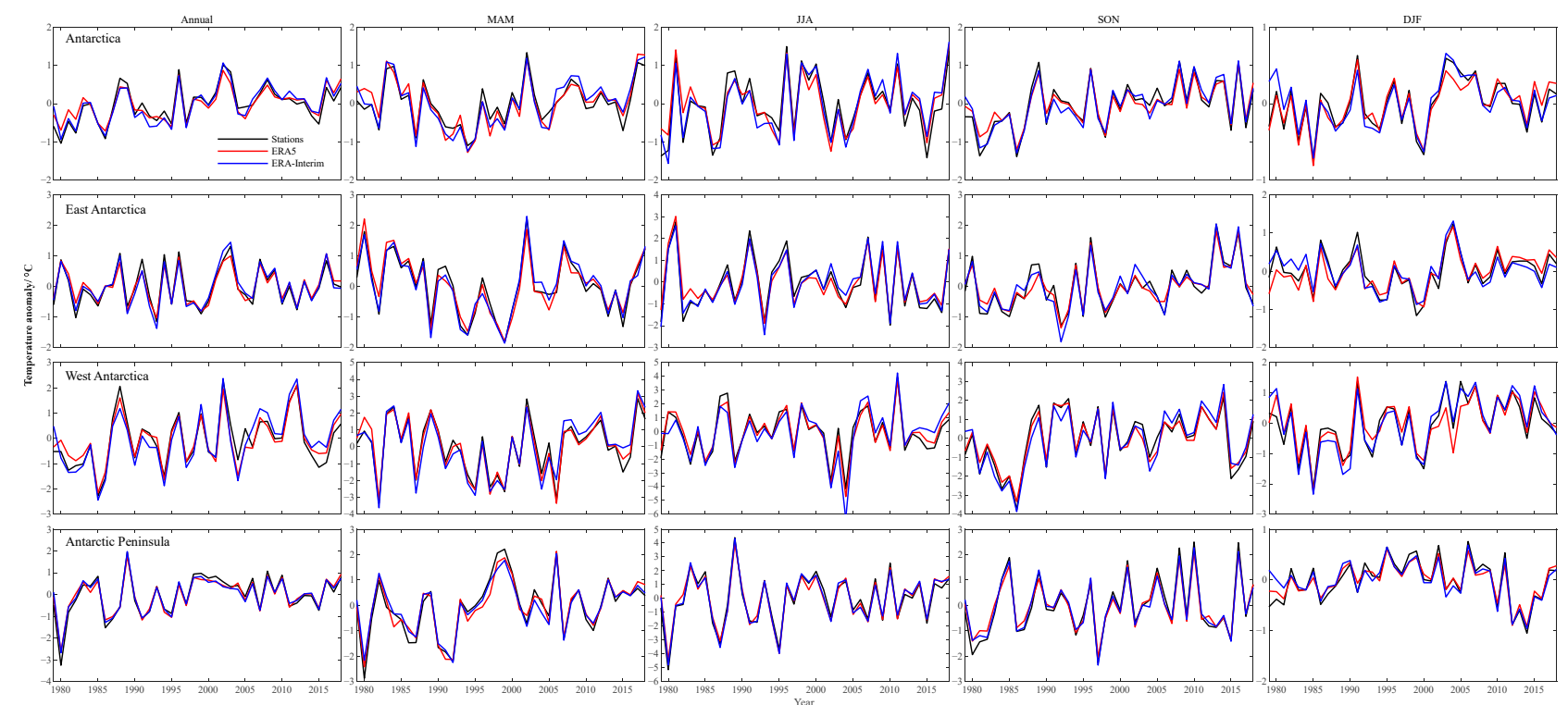

Figure 3. Time series of annual, autumn (MAM), winter (JJA), spring (SON), and summer (DJF) mean temperature anomalies from stations and the corresponding values of ERA5, and ERA-Interim.

The correlations, mean bias, and ratio of SDs between observations and the corresponding data from ERA reanalyses at Antarctic coastal and inland stations are shown in Figure 4 , and the correlations pass the test of significance $(p<0.05)$. ERA5 presents the highest correlations in spring for both coastal and inland stations, with significant correlation coefficients of 0.93 and 0.94, respectively. Compare to ERA-Interim, ERA5 has higher correlations in MAM and JJA at coastal stations, and lower correlations at inland stations in these seasons. ERA-Interim always shows cold bias at coastal stations and warm bias at inland stations; somewhat differently, ERA5 has cold bias in DJF at inland stations, indicating that the cold biases seen previously for the whole continent are caused by the coastal stations. The mean bias at coastal stations is always smaller than that of inland stations in all annual and seasonal mean temperature, and both of the ERA reanalyses show this feature. For coastal stations, biases in ERA5 are smaller than in ERA-Interim for all seasons with the exception of austral summer. In MAM, ERA-Interim has the greatest bias of 0.99 and $-3.25{ }^{\circ} \mathrm{C}$ for coastal and inland stations, respectively. For ERA5, only inland stations have an SD value higher than the observations in MAM, and the RSD of ERA-Interim is greater than 1 in autumn, winter, and annually at coastal stations. 

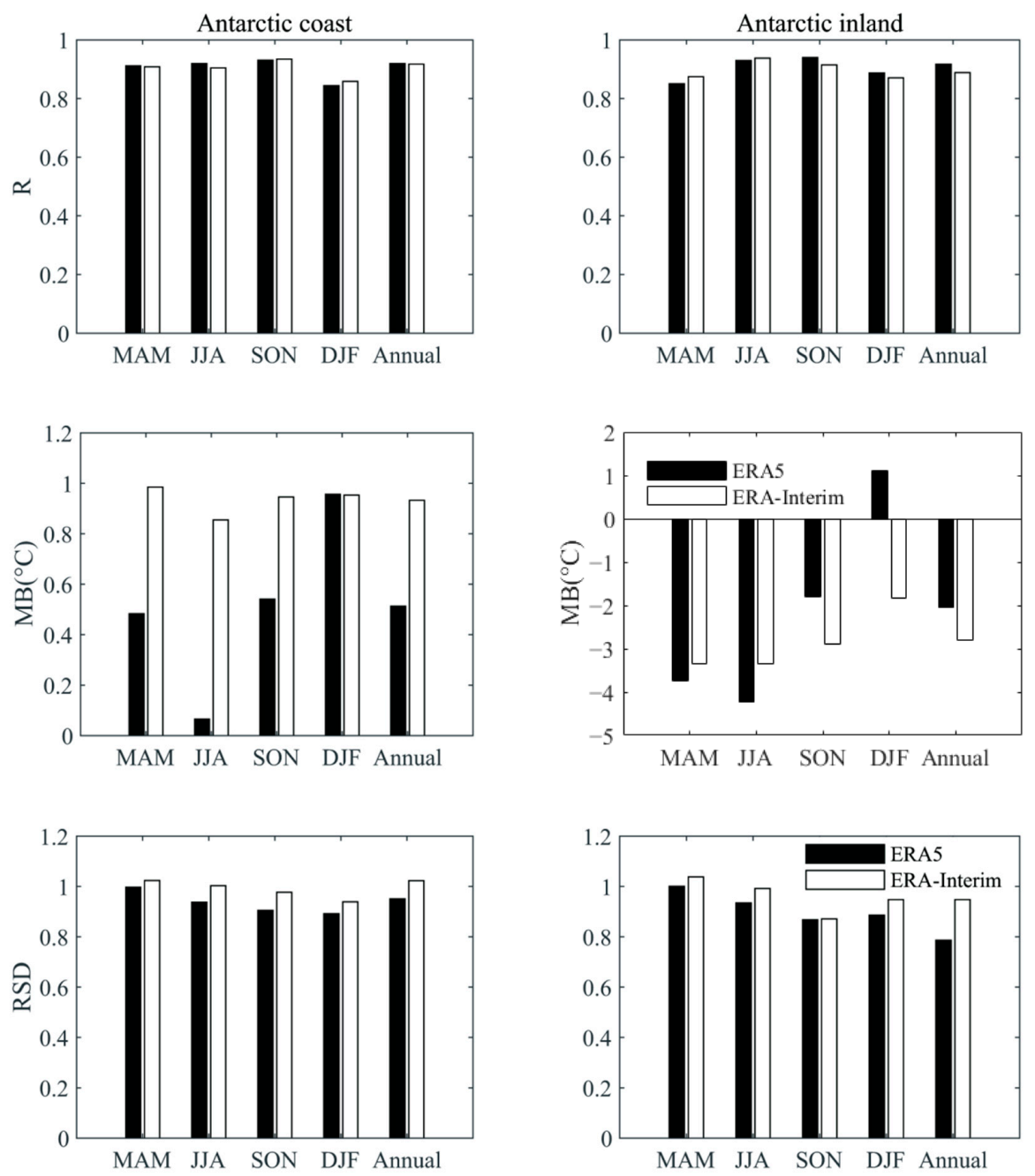

Figure 4. Correlation coefficient (R), MB $\left({ }^{\circ} \mathrm{C}\right)$, and RSD of autumn (MAM), winter (JJA), spring (SON), summer (DJF), and annual mean temperatures for ERA5 and ERA-Interim at Antarctic coastal and inland stations. Note: The correlation coefficients are all significant at the $95 \%$ confidence interval.

\subsection{The Performance of ERA5 over the Three Subregions in Antarctica}

The trend of Antarctic temperature is unclear now, and the tendency and the number of weather stations may differ among regions, therefore, we divided Antarctica into three subregions, including East Antarctica, West Antarctica, and the Antarctic Peninsula (Figure 1) to further explore the performance of ERA5. The correlation coefficients, bias, and ratio of the SDs of ERA5 and the differences in these variables between ERA5 and ERAInterim for monthly temperature measurements at 41 meteorological stations are shown in Figure 5. It is worth noting that the correlation coefficients here are all significant at the $95 \%$ confidence interval. For monthly temperature, the correlation coefficients between ERA5 and observations were generally high, with correlations higher than 0.95 at every one of the 41 stations selected, and the high correlations related to the temperature data have been assimilated into the reanalyses. The difference between the correlation coefficients of ERA5 and ERA-Interim is fairly small, and the division between them is less than 0.01. As shown in Figure 5b, ERA-Interim shows a higher linear relationship at stations located in East Antarctica and most stations in the Antarctic Peninsula, whereas ERA5 exhibits a stronger linear relationship with the observations on the Ross Ice Shelf. For ERA5, warm bias prevails for stations located at the interior of the East Antarctica, and there is no distinct pattern of bias over the coastal East Antarctica, West Antarctica, and Antarctic 
Peninsula stations. Compared with ERA-Interim, lower bias in ERA5 can be found at 26 stations, and the biggest difference between ERA5 and ERA-Interim occurs at McMurdo. For ERA5, eight stations have a higher SD value than the observations (Belgrano II, Cape Ross, Marble Point, Marilyn, Mario Zucchelli, O'Higgins, Rothera, and San Martin), and only two stations have ERA5 SD values that are more than 20\% lower (Dome C II and Marambio). ERA-Interim RSD values are higher than that those of ERA5 at 32 stations, and the SD value for ERA-Interim is higher than observations at 16 stations.
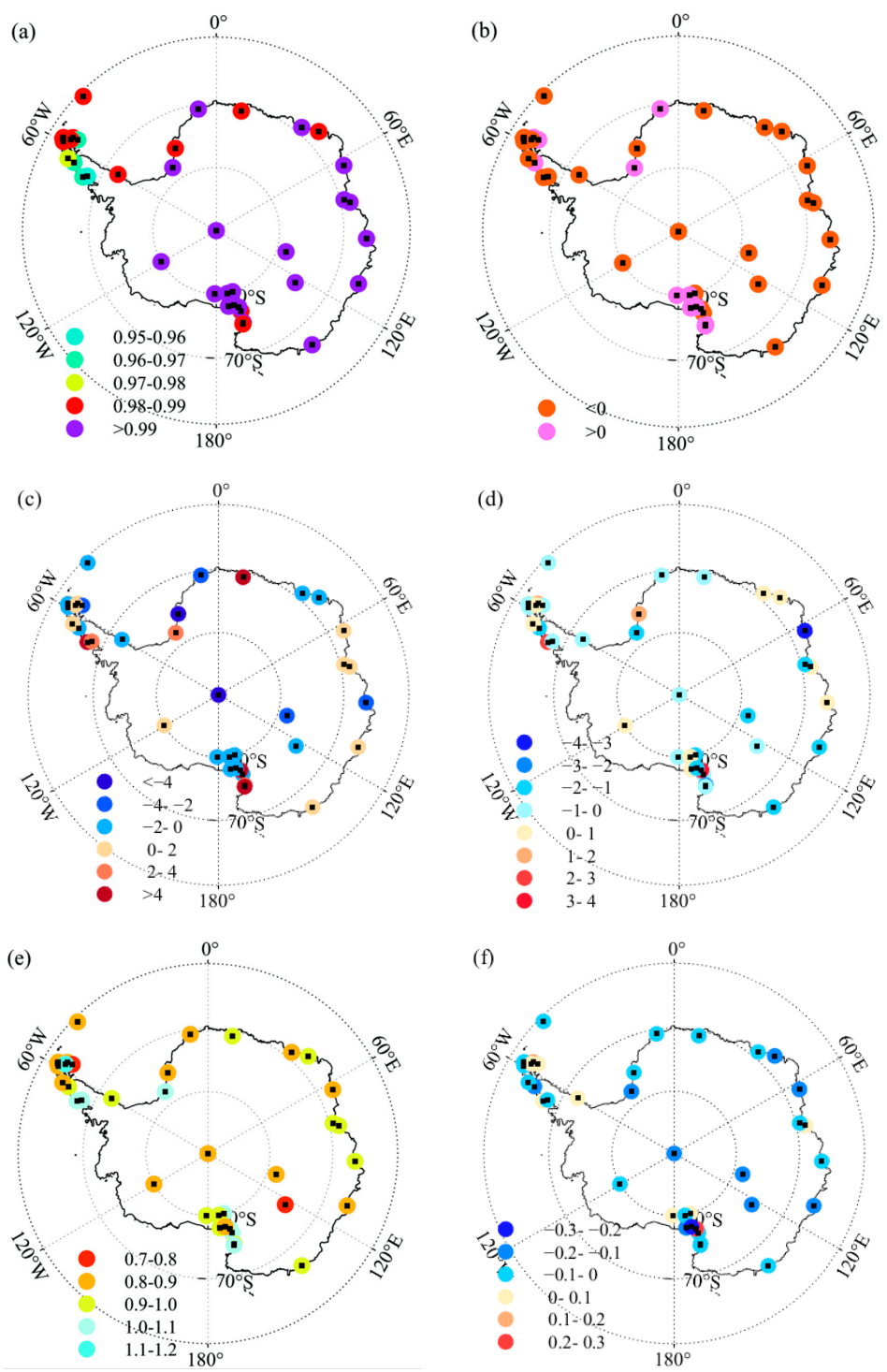

Figure 5. R (a), bias (c), and RSD (e) of monthly air temperature simulation for 41 stations from ERA5 and the difference of R (b), bias (d), and RSD (f) between ERA5 and ERA-Interim. Note: The correlation coefficients are all significant at the $95 \%$ confidence interval.

Figure 6 exhibits the correlations of ERA5 for annual and seasonal temperature and the difference between these correlations and those for ERA-Interim. Generally, the correlation coefficients between ERA5 and observations are fairly high for annual and seasonal temperature, with significant correlation coefficients $(p<0.05)$ higher than 0.80 at most stations. Compared with ERA-Interim, ERA5 exhibits winter temperature better, with relatively high correlation coefficients at 21 stations. ERA5 always has a stronger linear relationship with observations at Esperanza, Schwerdtfeger, and Scott Base, and the biggest difference between ERA5 and ERA-Interim occurs at Scott Base for annual temperature, where the correlation coefficient of ERA5 is 0.23 higher than that of ERA-Interim. Figure 7 
shows the same content as Figure 6 but for bias. In general, the bias values $\left(<2.00{ }^{\circ} \mathrm{C}\right)$ are relatively low at stations located at the coastal area of East Antarctica. For annual and seasonal temperature, ERA5 always has a warm bias at 8 stations (Amundsen-Scott, Butler Island, Halley, Marambio, Mirny, Neumayer, Schwerdtfeger, and Scott Base), and a cold bias is shown at 14 stations (Belgrano II, Byrd, Esperanza, King Sejong, Manuela, Marble Point, Mario Zucchelli, Mawson, McMurdo, Novolazarevskaya, O'Higgins, Palmer, Rothera, San Martin, and Zhongshan), and ERA5 shows warm biases at the inland stations (Vostok, Amundsen-Scott, and Dome C II) for the non-summer mean temperature. The smallest bias of ERA5 occurs at Faraday in MAM, and the data from ERA5 is lower than observations only by $0.01{ }^{\circ} \mathrm{C}$. The greatest cold and warm bias can be found at Mario Zucchelli and Halley in the austral winter, with values of -6.94 and $11.61{ }^{\circ} \mathrm{C}$, respectively. Compared with ERA-Interim, ERA5 exhibits lower bias at 10 stations (Dumont d'Urville, Faraday, Gill, Manuela, Marilyn, Mawson, San Martin, Scott Base, and Zhongshan) for all annual and seasonal temperatures, and higher bias always be found at Esperanza, Halley, Marble Point, Mirny, O'Higgins, Rothera, and Schwerdtfeger. At Scott Base station, warm bias is shown in all annual and seasonal temperatures in ERA5, while ERA-Interim shows cold bias, and a cold bias of $3.96{ }^{\circ} \mathrm{C}$ occurs for winter temperature in ERA-Interim, whereas ERA5 has a warm bias of $2.40^{\circ} \mathrm{C}$, which is the largest contrast between ERA5 and ERA-Interim. In particular, a large contrast in bias between autumn and winter is exhibited at Mawson and McMurdo station, which represent as ERA-Interim shows large bias larger than $5^{\circ} \mathrm{C}$, but the bias in ERA5 is lower than $1^{\circ} \mathrm{C}$. ERA5 bias is bigger than ERA-Interim in JJA, and smaller bias are shown in SON and annual temperature at inland stations. Compared with ERA-Interim, the smaller bias in ERA5 occurs at five stations (Zhongshan, Casey, Dumont d'Urville, Mawson, Neumayer) at the coastal areas of East Antarctica in all annual and seasonal temperature, and higher bias always at Mirny station. At Byrd station located at West Antarctica, ERA5 represents bigger bias than that of ERA-Interim except for autumn. McMurdo Station and Scott Base, both on Ross Island and only $3 \mathrm{~km}$ apart. The temperature in ERA5 at McMurdo Station are always colder than observations, whereas those at Scott Base are warmer, indicating that the temperature of ERA5 reanalysis is influenced by small-scale topographical differences.
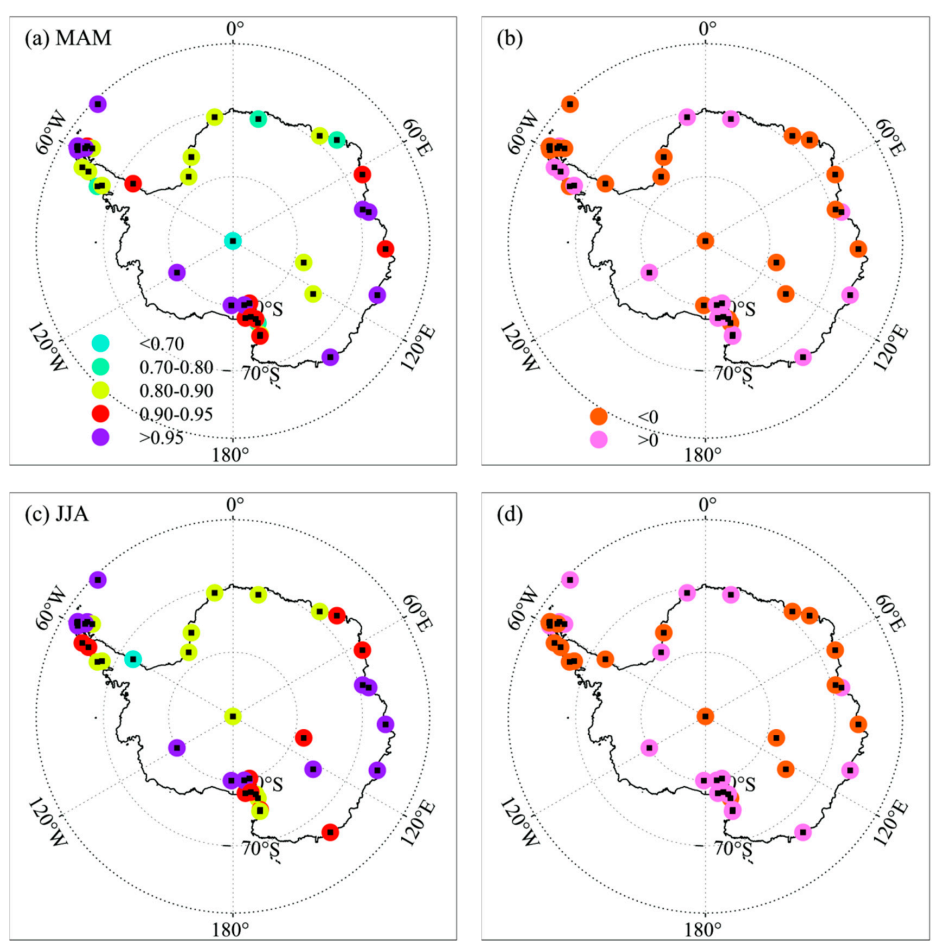

Figure 6. Cont. 

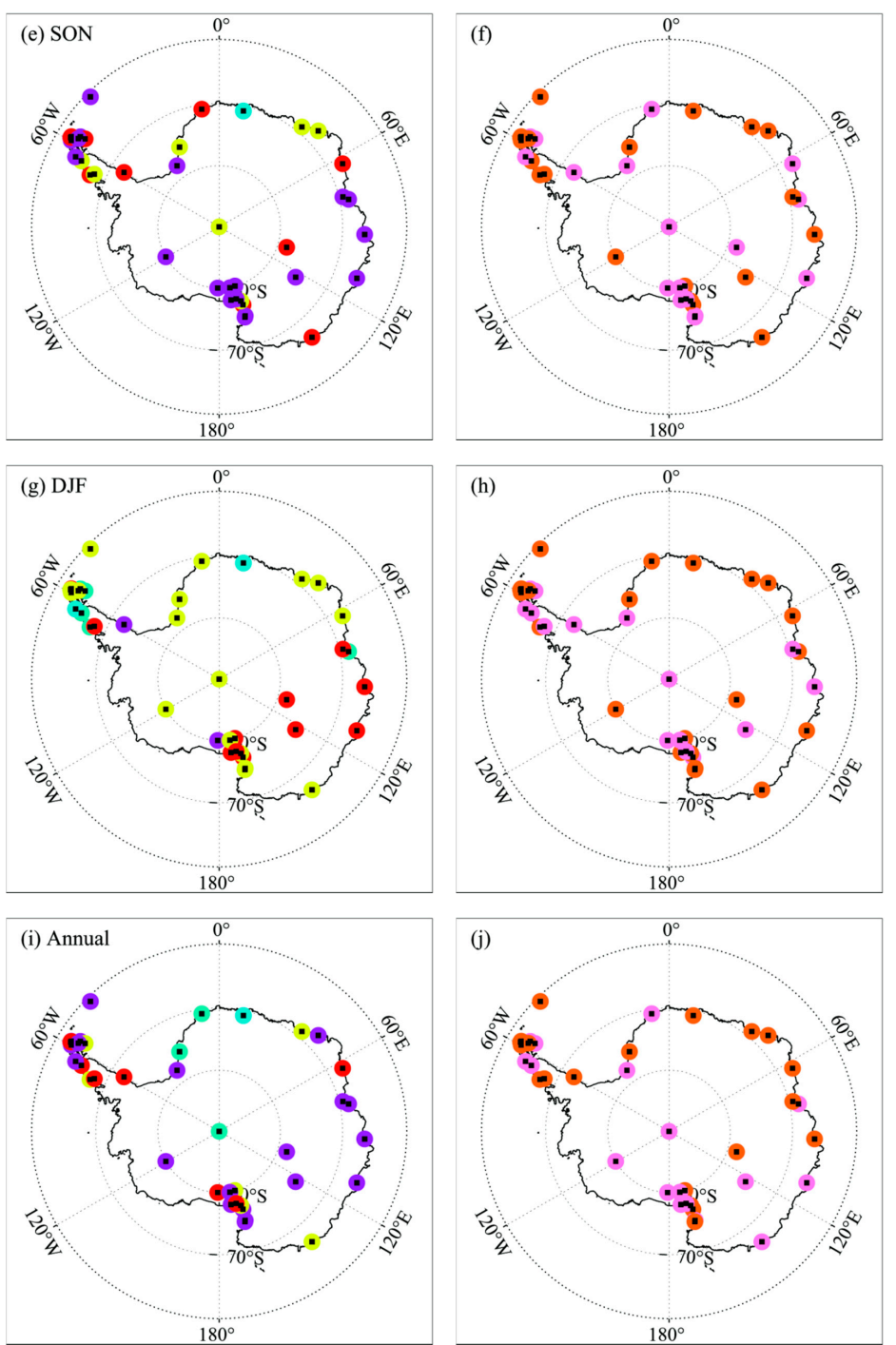

Figure 6. R of ERA5 for austral seasons of autumn (a), winter (c), spring (e), summer (g), annual mean (i), and the difference of it between ERA5 and ERA-Interim in autumn (b), winter (d), spring (f), summer (h), and annual mean (j). Note: The correlation coefficients are all significant at the $95 \%$ confidence interval. 

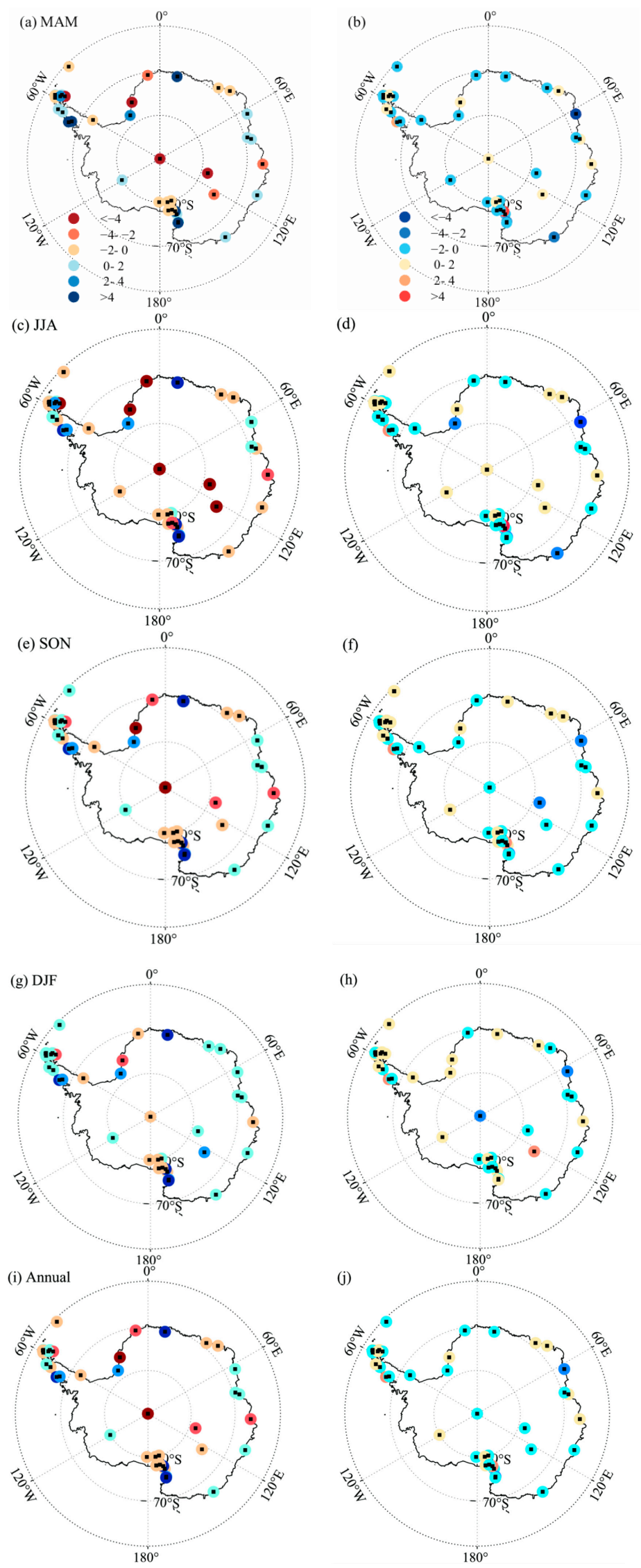

Figure 7. Bias $\left({ }^{\circ} \mathrm{C}\right)$ of ERA5 for austral seasons of autumn (a), winter (c), spring (e), summer (g), annual mean (i), and the difference of it between ERA5 and ERA-Interim in autumn (b), winter (d), spring (f), summer (h), and annual mean (j). 
In Figure 8, we plot six selected stations (Amundsen-Scott, Byrd, Marambio, Novolazarevskaya, Scott Base, and Vostok) located in central Antarctica, West Antarctica, the Antarctic Peninsula, the East Antarctica coast, the Ross Ice Shelf, and the interior of East Antarctica, respectively. For the six stations, ERA5 has slightly lower correlation $(\mathrm{R}<0.8)$ at Amundsen-Scott and Novolazarevskaya, as shown in Figure 6i, and the bias of ERA5 is larger than that of ERA-Interim only at Byrd. At Novolazarevskaya station, the data from ERA5 has a poor linear relationship with observations before 2000, but subsequently fit the observation data well. The temperature from ERA5 shows obvious disparity at Scott Base and Vostok relative to ERA-Interim. For Marambio, ERA5 shows the same warming as station data during the period.

ERA5 has average annual temperature biases of $0.51,-0.66$, and $0.58{ }^{\circ} \mathrm{C}$ in East Antarctica, West Antarctica, and the Antarctic Peninsula (Table 3), respectively. The corresponding biases from ERA-Interim are $0.97,0.03$, and $0.23^{\circ} \mathrm{C}$, which indicates a more accurate performance of ERA5 for annual temperature over East Antarctica. Table 2 summarizes the correlation between ERA reanalyses and observations over the Antarctica and its three subregions for annual and seasonal temperature means. Generally, we can conclude that ERA5 performs better over East Antarctica with exception of DJF, and it exhibits a high linear relationship with observations and small bias in other cases. Compared with ERA-Interim, ERA5 has a lower correlation and higher bias in DJF in East Antarctica, and the highest bias in ERA reanalyses occurs in this season, with the cold bias of 1.53 and $1.25^{\circ} \mathrm{C}$ for ERA5 and ERA-Interim, respectively. Over West Antarctica, warm bias and higher correlation coefficients prevail for annual and seasonal temperature means in ERA5. Especially, the highest correlation coefficient of ERA5 is 0.97, occurring in West Antarctica in SON, and the corresponding value of ERA-Interim is 0.96 . The biggest difference between temperature from ERA5 and observations in West Antarctica is found in JJA, with a warm bias of $1.25^{\circ} \mathrm{C}$. In the Antarctic Peninsula, ERA5 always shows cold bias, and ERA-Interim exhibits a warm bias in JJA. In general, a higher bias and lower correlation coefficients of ERA5 relative to ERA-Interim are observed in this area. For ERA5, lower performance in the Antarctic Peninsula is shown in DJF, with high bias values and low liner relationship with stations records. We conclude that ERA5 performs well in representing East Antarctic and West Antarctic temperature, especially in SON, with the bias lower than $0.80{ }^{\circ} \mathrm{C}$ and correlation coefficients higher than 0.90. The anomalies from ERA5 and ERA-Interim coincide with common variability from observations over the three subregions, especially in the Antarctic Peninsula (Figure 3). The mean autumn temperature over East Antarctica exhibits a shift change in circa 2002, and the change is also found at Antarctica and West Antarctica in MAM. However, this phenomenon does not occur in the Antarctic Peninsula.

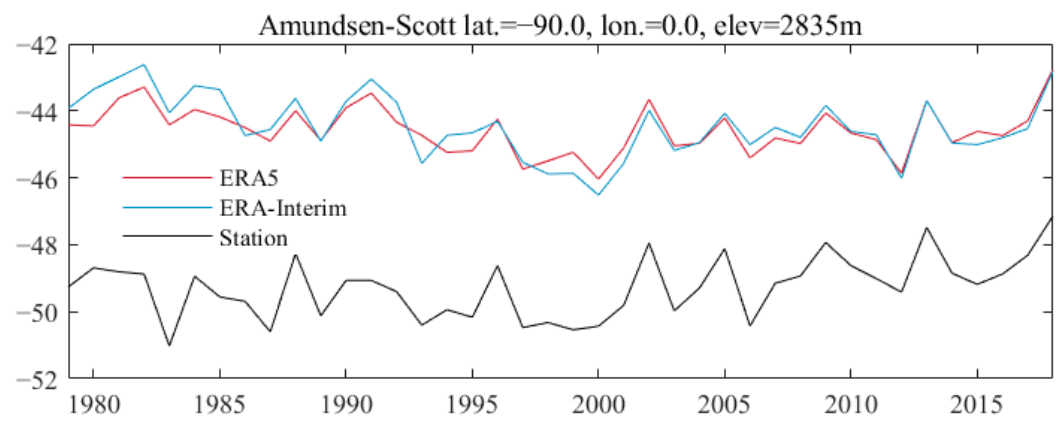

Figure 8. Cont. 

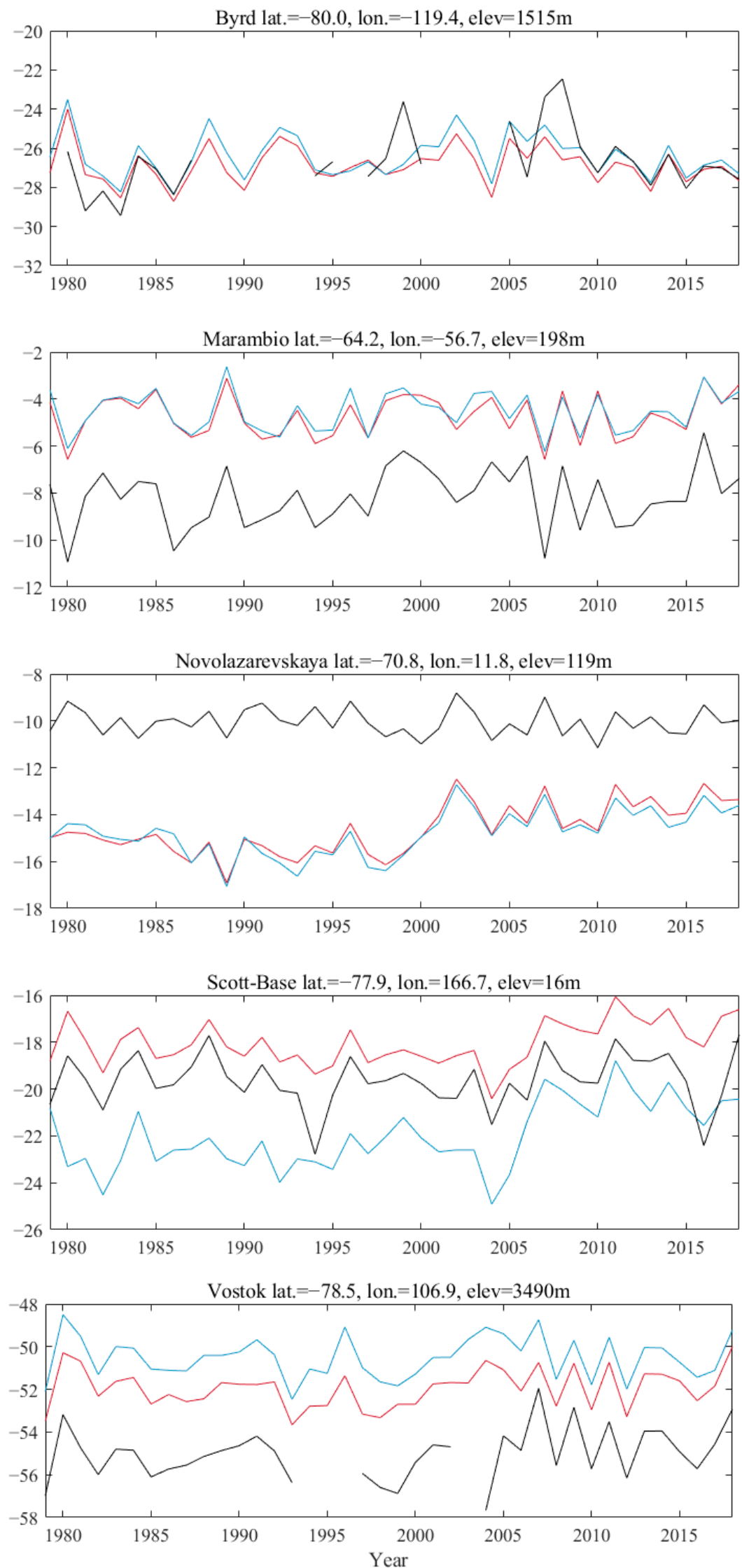

Figure 8. Comparisons between station time series and ERA5 and ERA-Interim at six selected stations located in central Antarctica, West Antarctica, Antarctic Peninsula, East Antarctica coast, Ross Ice Shelf, and the interior of East Antarctica. 
In Figure 9, we compare the spatial trend of austral seasons for the whole of Antarctica from ERA5 and ERA-Interim during the period 1979-2018. In MAM, the trend of ERA5 is in broad agreement with that from ERA-Interim; both of them show significant warming trends in the western Antarctic Peninsula, while the trend of ERA-Interim in this region shows greater warming than that of ERA5. In JJA, there is an obvious warming trend on the Ross Ice Shelf in ERA-Interim, while the trend value of ERA5 is lower than that of ERA-Interim. Significant warming trends are prevalent in East Antarctica in SON, and the trend is stronger and broader than shown by ERA-Interim. Over all seasons, the greatest difference between the trend of ERA5 and ERA-Interim occurs in DJF. In this season, ERA5 reveals a slight warming trend over the area in the interior of East Antarctica, whereas ERA-Interim shows a significant cooling trend in that region. The annual and seasonal mean temperature trends are summarized for the Antarctic subregions in Table 4. Annual and seasonal temperature trends in ERA5 and ERA-Interim are statistically significant in East Antarctica, and the cooling trends in observations in SON do not pass the significance test. The trends in ERA reanalyses and observations are all negative in East Antarctica in all annual and seasons, and the fastest cooling trend appears in MAM, and the cooling rate of this season is more than $1{ }^{\circ} \mathrm{C}$ per decade. In West Antarctica, the ERA5 trends are similar to observation trends, whereas there is a difference between ERA 5 trends and ERA-Interim in SON, as reflected in a warming trend in ERA-Interim while a cooling trend is observed in ERA5. ERA5 exhibits a significant cooling trend in annual data, MAM, and JJA, and the trends from ERA-Interim always fail to pass the significance test. It is also worth mentioning that the ERA5 shows a faster cooling rate than ERA-Interim and observations in West Antarctica. Over the Antarctic Peninsula, trends of annual and seasonal temperature means in ERA reanalyses and observations are not significant. ERA5 presents a warming trend with the exception of DJF, as is the case for ERA-Interim and station records. Compared with ERA-Interim, the difference between ERA5 trends and observations in the Antarctic Peninsula is relatively small in JJA and DJF.
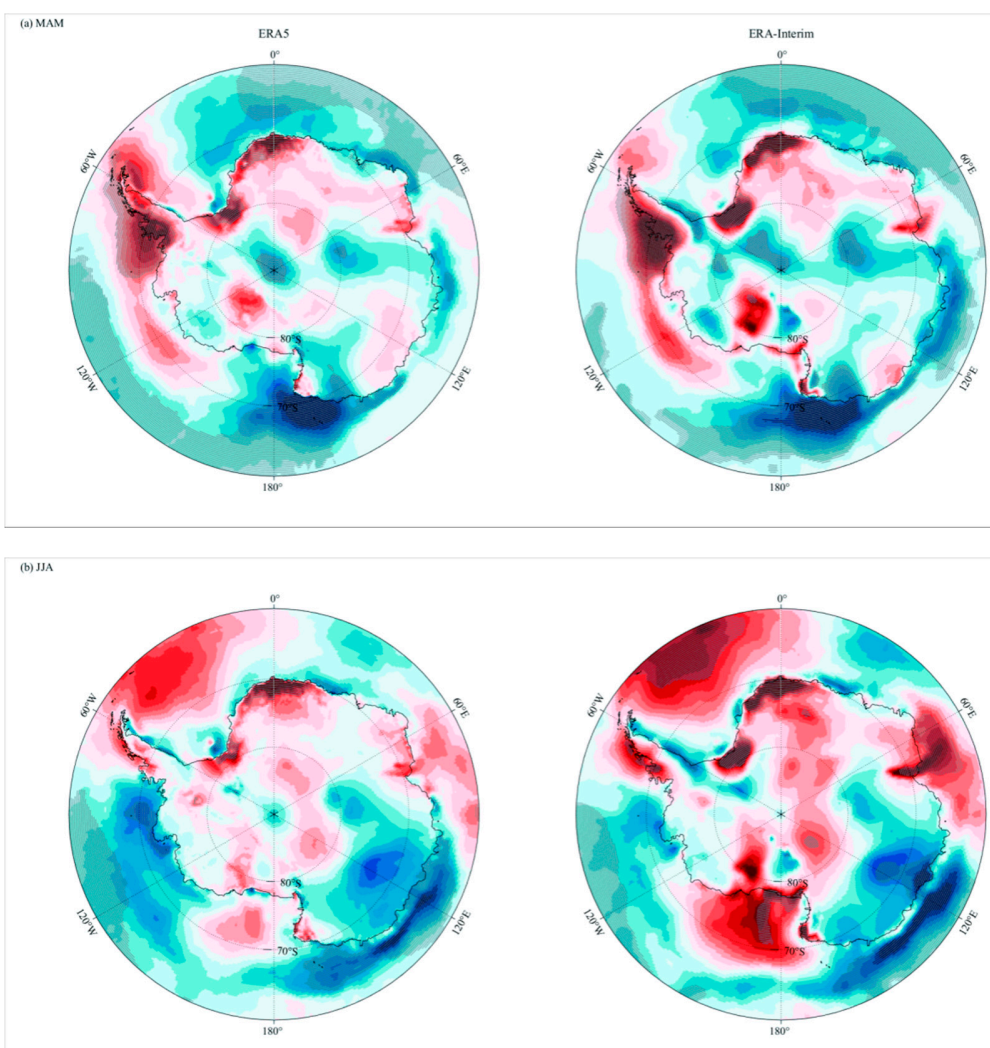

Figure 9. Cont. 

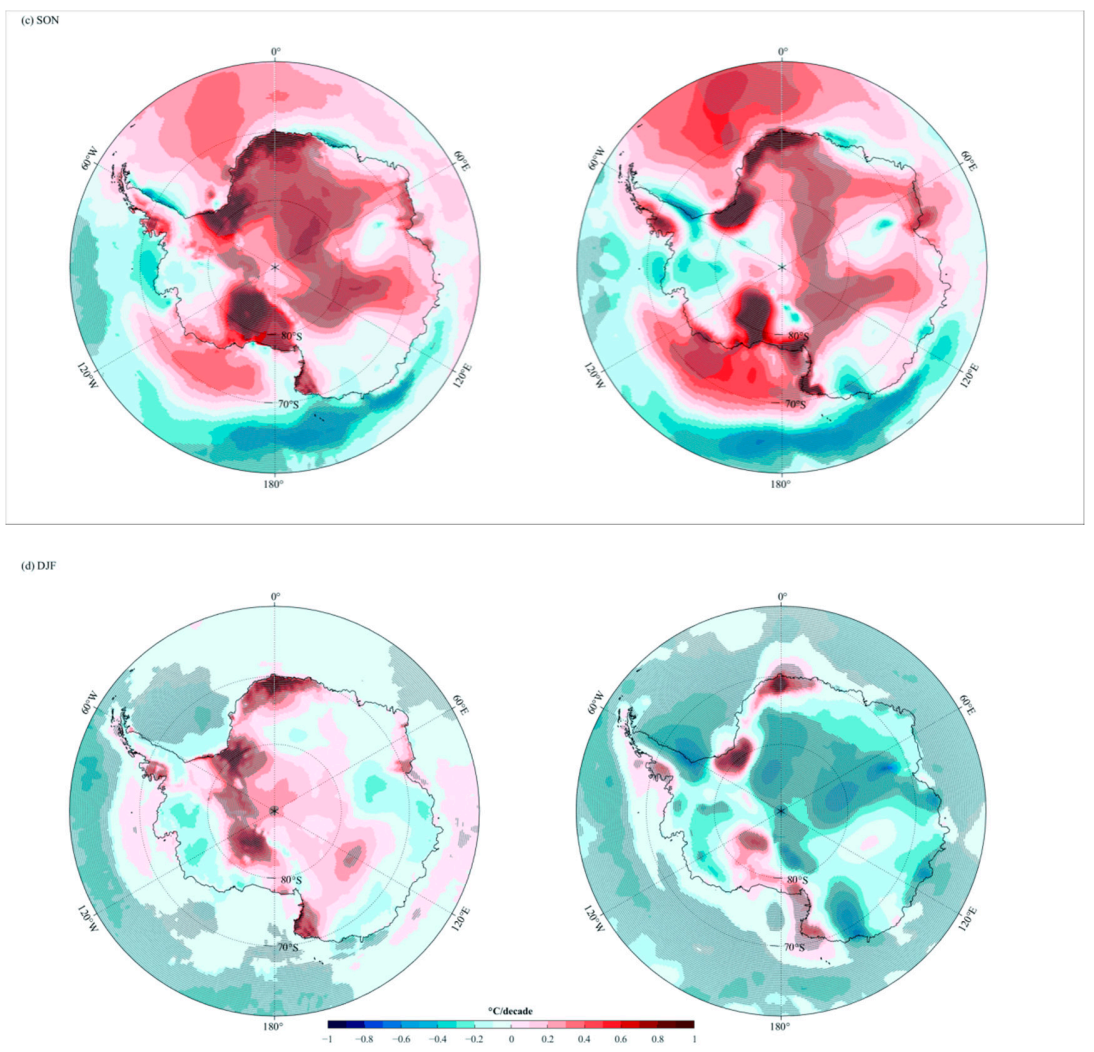

Figure 9. Comparison of the trends between ERA5 and ERA-Interim over the Antarctica for austral seasons of autumn (a), winter (b), spring (c), and summer (d) during the period 1979-2018. The gray shaded areas with trends significant at the $95 \%$ confidence level.

Table 4. Trends $\left({ }^{\circ} \mathrm{C} /\right.$ decade) of annual, autumn (MAM), winter (JJA), spring (SON), and summer (DJF) mean temperature from Stations, ERA5, and ERA-Interim calculated for the 1979-2018 period. The bold font shows that the trend is significant at the $95 \%$ confidence interval.

\begin{tabular}{ccccc}
\hline & East Antarctica & West Antarctica & $\begin{array}{c}\text { Antarctic } \\
\text { Peninsula }\end{array}$ \\
\hline \multirow{3}{*}{ Annual } & ERA5 & $\mathbf{- 0 . 7 0} \pm \mathbf{0 . 2 4}$ & $\mathbf{- 0 . 4 2} \pm \mathbf{0 . 3 7}$ & $0.18 \pm 0.23$ \\
& ERA-Interim & $\mathbf{- 0 . 6 9} \pm \mathbf{0 . 2 3}$ & $-0.06 \pm 0.36$ & $0.18 \pm 0.24$ \\
& Stations & $\mathbf{- 0 . 5 6} \pm \mathbf{0 . 2 9}$ & $-0.31 \pm 0.33$ & $0.17 \pm 0.26$ \\
MAM & ERA5 & $\mathbf{- 1 . 2 0} \pm \mathbf{0 . 3 3}$ & $\mathbf{- 0 . 7 2} \pm \mathbf{0 . 6 4}$ & $0.24 \pm 0.32$ \\
& ERA-Interim & $\mathbf{- 1 . 1 0} \pm \mathbf{0 . 3 3}$ & $-0.23 \pm 0.60$ & $0.17 \pm 0.31$ \\
& Stations & $\mathbf{- 1 . 0 3} \pm \mathbf{0 . 3 4}$ & $\mathbf{- 0 . 5 5} \pm \mathbf{0 . 5 9}$ & $0.19 \pm 0.34$ \\
JJA & ERA5 & $\mathbf{- 0 . 8 6} \pm \mathbf{0 . 4 3}$ & $\mathbf{- 0 . 8 0} \pm \mathbf{0 . 5 9}$ & $0.20 \pm 0.53$ \\
& ERA-Interim & $\mathbf{- 0 . 7 4} \pm \mathbf{0 . 4 4}$ & $-0.26 \pm 0.61$ & $0.27 \pm 0.55$ \\
& Stations & $\mathbf{- 0 . 6 9} \pm \mathbf{0 . 5 0}$ & $\mathbf{- 0 . 6 2} \pm \mathbf{0 . 5 7}$ & $0.17 \pm 0.56$ \\
SON & ERA5 & $\mathbf{- 0 . 5 2} \pm \mathbf{0 . 2 9}$ & $-0.29 \pm 0.47$ & $0.05 \pm 0.28$ \\
& ERA-Interim & $\mathbf{- 0 . 4 8} \pm \mathbf{0 . 2 9}$ & $0.12 \pm 0.48$ & $0.06 \pm 0.30$ \\
& Stations & $-0.33 \pm 0.36$ & $-0.16 \pm 0.48$ & $0.10 \pm 0.33$ \\
DJF & ERA5 & $\mathbf{- 0 . 3 9} \pm \mathbf{0 . 2 1}$ & $-0.12 \pm 0.30$ & $-0.03 \pm 0.09$ \\
& ERA-Interim & $\mathbf{- 0 . 5 6} \pm \mathbf{0 . 1 8}$ & $-0.02 \pm 0.31$ & $-0.07 \pm 0.10$ \\
& Stations & $\mathbf{- 0 . 3 8} \pm \mathbf{0 . 2 2}$ & $-0.06 \pm 0.27$ & $-0.05 \pm 0.11$ \\
\hline
\end{tabular}

Figure 10 illustrates the regression trends of seasonal mean temperature from six select stations from the ERA reanalyses and Antarctic observations as illustrated in Figure 8. At the Byrd, Marambio, Novolazarevskaya, and Scott Base stations, ERA5 exhibits the same trend as ERA-Interim in seasonal temperature. At Amundsen-Scott and Vostok, a warming trend is captured by ERA5 and observations in SON and DJF, whereas a cooling trend is 
found in ERA5 in MAM and JJA, in contrast to the warming trend in observations. There is no significant trend at Byrd, and ERA5 displays a different sign compared with observations in JJA and DJF. At Marambio, the same sign is captured by ERA5 and observation with exception of DJF. At Novolazarevskaya and Scott Base, the warming trend in ERA5 is prevalent for all seasons, while observation shows a cooling trend in MAM and DJF. At Vostok, ERA5 agrees well with the observed warming trend in SON, and divergence is shown between ERA-Interim and station records, except for austral spring.
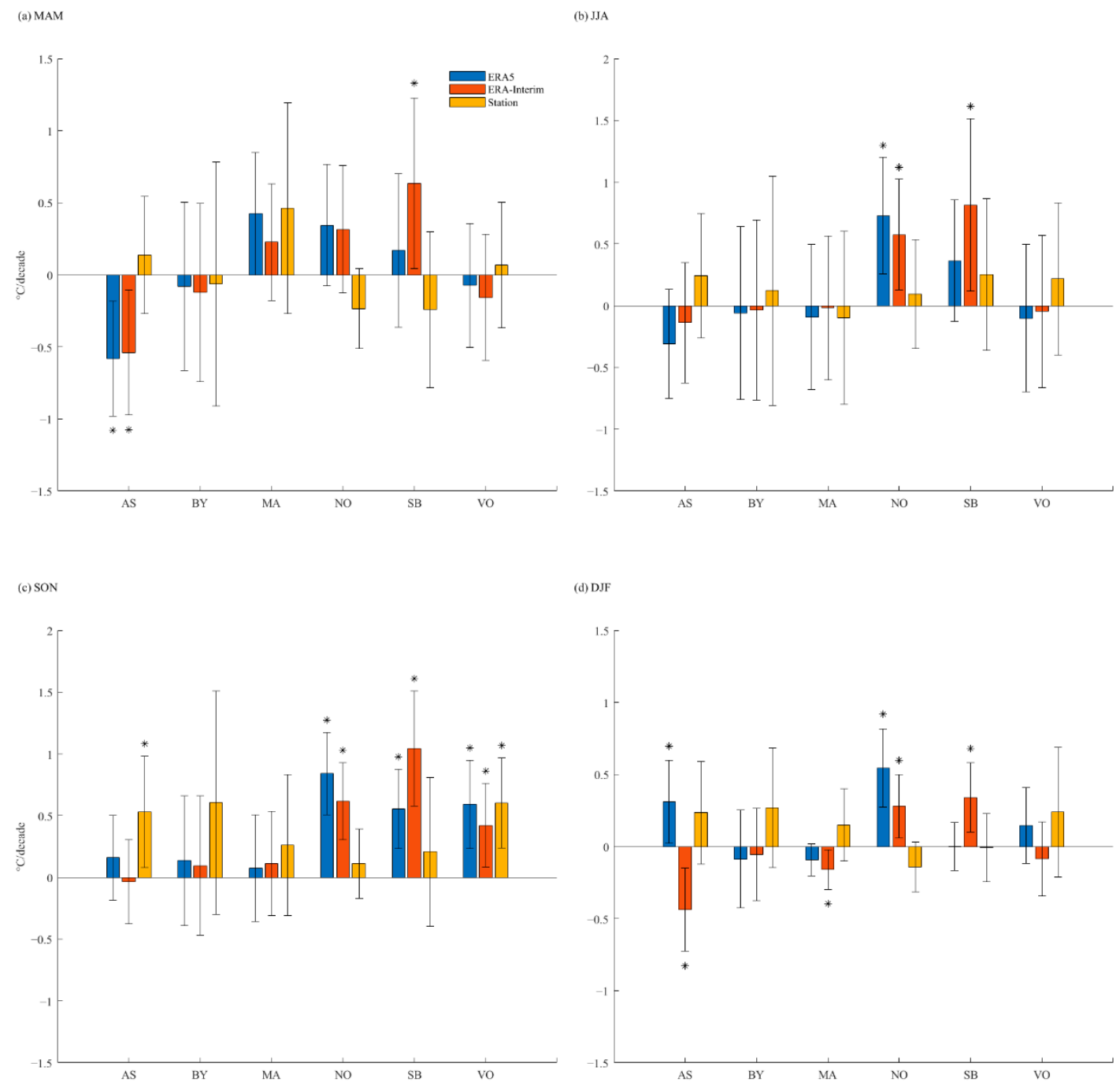

Figure 10. Comparison of trends between reanalyses and observations at six selected stations as illustrated in Figure 8 for austral seasons of autumn (a), winter (b), spring (c), and summer (d) during the period 1979-2018. AS = Amundsen-Scott; $\mathrm{BY}=$ Byrd; $\mathrm{MA}=$ Marambio; $\mathrm{NO}=$ Novolazarevskaya; $\mathrm{SB}=$ Scott Base; $\mathrm{VO}=$ Vostok. " “* "represents that the trend is significant at the $95 \%$ confidence interval.

\section{Discussion}

ERA5 has the ability to approximate the Antarctic near-surface temperature measured by weather stations. Although ERA reanalyses can accurately estimate the temperature, they always exhibit bias compared with the observations for the assimilation observation data as well as biases in boundary forcing, and reanalysis presents average data for the grid cell, while the measured data are from a specific point [28,43]. A previous study assessed the applicability of eight types of reanalysis datasets in Antarctica, and the results showed that ERA-Interim has the highest correlations among them and can capture the interannual variability in monthly air temperature, which results from the higher 
resolution, application of the $2 \mathrm{~m}$ temperature observations and background temperatures in an optimal interpolation scheme $[16,18]$. There is only a small distinction between the correlations of ERA5 and ERA-Interim, although ERA5 has higher spatial and temporal resolutions, and more in situ observations and satellite data are used, and this phenomenon may be caused by imprecisely measured data. The correlations of Climate Forecast System Reanalysis (CFSR) and Modern-Era Retrospective Analysis for Research and Applications updated version (MERRA-2) are high in Antarctica, and MERRA-2 can capture the monthly temperature over the Antarctic inland stations [16], but their correlations are lower than those of ERA5, which may be mainly related to the differences in dimensions of the assimilation systems used. In Antarctica, the performance of 20th century reanalyses including the ECMWF twentieth century reanalysis (ERA-20C), a new coupled 20th-century climate reanalysis product (CERA-20C) and 20th-Century Reanalysis (20CR) from the National Oceanic and Atmospheric Administration (NOAA) is not satisfactory and they cannot capture the long-term temperature changes, and they show temporal changes due to the limited number of observations [16], and ERA5 performs better than them. Japanese 55year Reanalysis (JRA-55) shows strong linear relationship with observations in the austral winter months for both inland and coastal stations, with correlation coefficients lower than 0.90 [16], and it is lower than that of ERA5, for which correlation coefficients are higher than 0.90 for inland stations and coastal mean in JJA. Reanalysis data shows minimum correlations in austral summer in Antarctica, small bias in DJF at inland stations and cold bias at coastal stations [16], and the same results also appear in ERA5. The warm bias in ERA5 in winter at inland stations is greater than that in ERA-Interim, and the warm bias in ERA-Interim is related to the overestimation of the surface turbulent sensible heat fluxes under very stable conditions [32]. The following several factors contribute to the seasonal variation. Air-sea-land interactions near the coast are difficult for the model to capture, and the melting of sea ice and snow cover near the coast in summer complicates regional temperature simulations because of albedo and thermal differences between coastal regions and inland regions [43-45]. Our results agree with previous research showing that ERAInterim shows a warm bias in the interior of East Antarctica for annual temperature, and the warm bias is most likely related to the limited ability to capture surface turbulent fluxes [28,31]. Many observations of temperature measured in Antarctica suffer from warm bias due to the solar radiation, especially in summer [46], indicating that ERA5 has a smaller cold bias in this season. In particular, ERA5 has a slightly warm bias of $0.01{ }^{\circ} \mathrm{C}$ in summer in West Antarctica, and ERA5 may show a larger warm bias actually. Although ERA reanalyses perform well in representing East Antarctic temperature, the ECMWF has flaws in parameterizing clouds, longwave radiation, and turbulent mixing in the cold and stable atmosphere over East Antarctica [45,47]. The coastal regions of Antarctica have complex terrains and landforms, with complicated and variable thermal properties, and this may be a factor in the difference between the observations and the reanalysis data [43]. It is noteworthy that the manual temperature data have been assimilated into the ERA5, so it is important to compare the data from ERA5 and AWS to make the comparison independent. For this, we compare the data from AWSs in Table 1 with the corresponding data in ERA5 and ERA-Interim, and the result is shown in Table 5. Clearly, ERA5 has the strongest linear relationship and the lowest bias with AWS in austral spring, and the strong linear relation also can be captured when we do the comparison including manual stations. ERA5 always has cold bias in all annual and seasonal temperature, while there is a warm bias of $4.72{ }^{\circ} \mathrm{C}$ in ERA-Interim in SON. 
Table 5. Correlation, bias $\left({ }^{\circ} \mathrm{C}\right)$, and RSD between data from AWSs and ERA reanalyses for annual, autumn (MAM), winter (JJA), spring (SON), and summer (DJF) mean temperatures at Antarctica.

\begin{tabular}{ccccc}
\hline & & R & Bias & RSD \\
\hline \multirow{2}{*}{ Annual } & ERA5 & 0.94 & 0.08 & 0.98 \\
& ERA-Interim & 0.95 & 1.45 & 1.00 \\
MAM & ERA5 & 0.91 & 1.09 & 1.05 \\
& ERA-Interim & 0.91 & 0.08 & 1.02 \\
JJA & ERA5 & 0.89 & 1.19 & 0.98 \\
SON & ERA-Interim & 0.88 & 0.21 & 0.98 \\
& ERA5 & 0.96 & 0.03 & 0.97 \\
DJF & ERA-Interim & 0.96 & -4.72 & 0.99 \\
& ERA5 & 0.91 & 0.31 & 1.01 \\
\hline
\end{tabular}

Note: The correlation coefficients are all significant at the 95\% confidence interval.

ERA5 reveals a cooling trend in austral summer in the Antarctic Peninsula, and Turner et al. (2016) have pointed out that the most rapid cooling trend occurs in the austral summer, and this drop is related to more frequent cold, east-to-southeasterly winds. Sea ice plays an important role in the temperature over the Antarctic Peninsula, and the changes in sea ice extent and duration are mainly controlled by Southern Annular Mode (SAM) and El Niño-Southern Oscillation (ENSO) $[13,48,49]$. The decline in stratospheric ozone concentrations is a part reason for the increase in the circumpolar westerlies and may account for the warming trends in the peninsula region in austral summer and autumn [50]. West Antarctic continental temperature increases primarily in austral winter and spring, and research concluded that the increasing tropical sea surface temperature affects the high-latitude atmospheric circulation in the Southern Hemisphere, which may accounts for the West Antarctic warming [50]. In ERA5, East Antarctica displays warming trends in spring, and significant warming is concentrated in the region above $80^{\circ} \mathrm{S}$ latitude. A cooling trend occurs in MAM and DJF, and the regional cooling is likely related to tropospheric flow, which is promoted by atmospheric circulation changes [15,51,52]. The cooling trend of ERA5 in East Antarctica indicates that ERA5 can describe the ozone-forced cooling of the troposphere that has been observed in the region since the late 1970s [15].

There are several temperature reconstructions in Antarctica based on different methods $[11,53,54]$. Monthly near-surface temperature anomalies in Antarctica for the period 1958-2012, based on 15 monthly instrumental temperature observations in combination with spatiotemporal temperature covariances, from CFSR (RECONCFSR) show the best performance [15]. Figure 11 compares the annual temperature trends for the entire Antarctic continent from RECONCFSR and ERA5 during the period 1979-2012. The trends of ERA5 are highly different from those of RECONCFSR. Positive trends occur in almost all grids of RECONCFSR over the Antarctic Peninsula, while ERA5 shows a negative trend over the northern Antarctic Peninsula islands. The opposite trends are found over East Antarctica; in particular, a significant cooling trend in central Antarctica is shown in the ERA5 output. From 1979 to 2010, an extensive negative trend predominated East Antarctica in 20CR, a positive trend was dominant in Antarctica in ERA-20C [28], while a positive trend occurs in northern East Antarctica in ERA5 in comparison. 


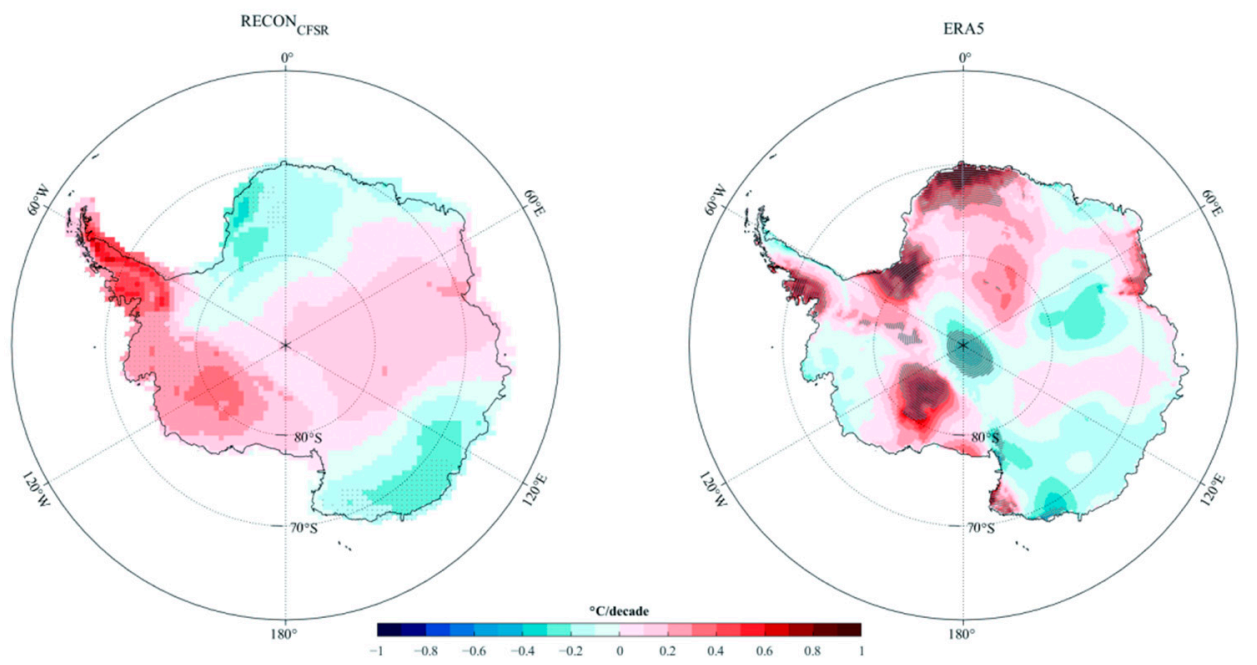

Figure 11. Trends in annual mean temperature from RECONCFSR and ERA5 during the period 1979-2012. The gray shaded areas with trends significant at the $95 \%$ confidence level.

\section{Conclusions}

Based on the monthly near-surface air temperature from 41 weather stations in Antarctica, compared with that of ERA-Interim, the performance of ERA5 has been assessed in all of Antarctica and the three subregions namely East Antarctica, West Antarctica, and the Antarctic Peninsula. The variability in annual and seasonal mean temperature can be reproduced by ERA5, although bias occurs. Over the whole of Antarctica, ERA5 presents a cold bias with the exception of JJA, while ERA-Interim shows a cold bias in all annual and seasonal means. The two reanalyses exhibit lower bias at coastal stations in all cases, and the lowest correlation occurs in DJF. For all stations, the correlations between ERA5 and monthly observations are higher than 0.95 , indicating a high linear relationship and good performance, and the difference between ERA5 and ERA-Interim is lower than 0.01. The significant correlations of ERA5 are higher than 0.80 at most stations in annual and seasonal mean temperatures. Generally, ERA5 has the highest linearity in SON, with significant correlation coefficients higher than 0.90 , and the lowest linear relationship is shown in DJF. There are regional differences in ERA5 capacity, with high correlations in West Antarctica and the Antarctic Peninsula. Compared with ERA5, ERA-Interim has a slightly higher linear relationship with observations in the Antarctic Peninsula. Warm bias in ERA5 prevails for the stations located in the interior of the Antarctica, and the biases for coastal stations are irregular. ERA5 shows a warm bias in East Antarctica except in JJA, a cold bias in West Antarctica and a warm bias on the Antarctic Peninsula. ERA5 exhibits the opposite biases in comparison with ERA-Interim in the three subregions in JJA. A cooling trend occurs in ERA5 and ERA-Interim over East Antarctica, and a warming trend occurs over the Antarctic Peninsula with the exception of DJF. We conclude that ERA5 performs well in Antarctica, but it is necessary to correct the biases to improve the reanalysis. Despite the bias present in ERA5, in Antarctica, with sparse in situ observations, ERA5 is the most up-to-date reanalysis model and can play an important role as an effective tool to study climate change.

Author Contributions: Conceptualization, J.Z. and A.X.; methodology, Y.W. (Yetang Wang); software, J.Z. and B.X.; validation, X.Q. and Y.W. (Yetang Wang); formal analysis, J.Z.; resources, J.Z.; data curation, Y.W. (Yicheng Wang) and B.X.; writing-original draft preparation, J.Z.; writing-review and editing, A.X. and X.Q.; visualization, J.Z.; supervision, A.X.; project administration, A.X. All authors have read and agreed to the published version of the manuscript.

Funding: This research was funded by National Natural Science Foundation of China, grant number 41671073 and 41476164. 
Institutional Review Board Statement: Not applicable.

Informed Consent Statement: Not applicable.

Data Availability Statement: The ERA5 data presented in this study are openly available at https:/ / cds.climate.copernicus.eu/\#!/search?text=ERA5\&type=dataset, ERA-Interim data presented in this study are openly available at https://apps.ecmwf.int/datasets/data/interim-full-daily/levtype= $\mathrm{sfc/,}$ and observations are openly available at https://legacy.bas.ac.uk/met/READER/surface (accessed on 2 February 2021).

Acknowledgments: We thank the European Center for Medium-Range Weather Forecasts and Scientific Committee on Antarctic Research for providing data to improve the paper.

Conflicts of Interest: The authors declared that they have no conflict of interest to this work. We declare that we have no financial and personal relationships with other people or organizations that can inappropriately influence our work.

\section{References}

1. Convey, P.; Bindschadler, R.; di Prisco, G.; Fahrbach, E.; Gutt, J.; Hodgson, D.A.; Mayewski, P.A.; Summerhayes, C.P.; Turner, J.; Consortium, A. Antarctic climate change and the environment. Antarct. Sci. 2009, 21, 541-563. [CrossRef]

2. Rintoul, S.R.; Chown, S.L.; DeConto, R.M.; England, M.H.; Fricker, H.A.; Masson-Delmotte, V.; Naish, T.R.; Siegert, M.J.; Xavier, J.C. Choosing the future of Antarctica. Nature 2018, 558, 233-241. [CrossRef] [PubMed]

3. Mai, Y.; Sheng, Z.; Shi, H.; Liao, Q.; Zhang, W. Spatiotemporal Distribution of Atmospheric Ducts in Alaska and Its Relationship with the Arctic Vortex. Int. J. Antennas Propag. 2020, 6, 9673289. [CrossRef]

4. $\quad$ Bronselaer, B.; Winton, M.; Griffies, S.M.; Hurlin, W.J.; Rodgers, K.B.; Sergienko, O.V.; Stouffer, R.J.; Russell, J.L. Change in future climate due to Antarctic meltwater. Nature 2018, 564, 53-58. [CrossRef] [PubMed]

5. Yuan, N.; Ding, M.; Huang, Y.; Fu, Z.; Xoplaki, E.; Luterbacher, J. On the Long-Term Climate Memory in the Surface Air Temperature Records over Antarctica: A Nonnegligible Factor for Trend Evaluation. J. Clim. 2015, 28, 5922-5934. [CrossRef]

6. Shepherd, A.; Ivins, E.; Rignot, E.; Smith, B.; van den Broeke, M.; Velicogna, I.; Whitehouse, P.; Briggs, K.; Joughin, I.; Krinner, G.; et al. Mass balance of the Antarctic Ice Sheet from 1992 to 2017. Nature 2018, 558, 219-222.

7. Rignot, E.; Mouginot, J.; Scheuchl, B.; van den Broeke, M.; van Wessem, M.J.; Morlighem, M. Four decades of Antarctic Ice Sheet 630 mass balance from 1979-2017. Proc. Natl. Acad. Sci. USA 2019, 116, 1095-1103. [CrossRef]

8. Seroussi, H.; Nowicki, S.; Payne, A.J.; Goelzer, H.; Lipscomb, W.H.; Abe-Ouchi, A.; Agosta, C.; Albrecht, T.; Asay-Davis, X.; Barthel, A.; et al. ISMIP6 Antarctica: A multi-model ensemble of the Antarctic ice sheet evolution over the 21st century. Cryosphere 2020, 14, 3033-3070. [CrossRef]

9. Bintanja, R.; van Oldenborgh, G.J.; Drijfhout, S.S.; Wouters, B.; Katsman, C.A. Important role for ocean warming and increased ice-shelf melt in Antarctic sea-ice expansion. Nat. Geosci. 2013, 6, 376-379. [CrossRef]

10. Trusel, L.D.; Frey, K.E.; Das, S.B.; Karnauskas, K.B.; Munneke, P.K.; van Meijgaard, E.; van den Broeke, M.R. Divergent trajectories of Antarctic surface melt under two twenty-first-century climate scenarios. Nat. Geosci. 2015, 8, 927-932. [CrossRef]

11. Steig, E.J.; Schneider, D.P.; Rutherford, S.D.; Mann, M.E.; Comiso, J.C.; Shindell, D.T. Warming of the Antarctic ice-sheet surface since the 1957 International Geophysical Year. Nature 2009, 457, 459-462. [CrossRef]

12. Turner, J.; Colwell, S.R.; Marshall, G.J.; Lachlan-Cope, T.A.; Carleton, A.M.; Jones, P.D.; Lagun, V.; Reid, P.A.; Iagovkina, S. Antarctic climate change during the last 50 years. Int. J. Climatol. 2005, 25, 279-294. [CrossRef]

13. Turner, J.; Lu, H.; White, I.; King, J.C.; Phillips, T.; Hosking, J.S.; Bracegirdle, T.J.; Marshall, G.J.; Mulvaney, R.; Deb, P. Absence of 21st century warming on Antarctic Peninsula consistent with natural variability. Nature 2016, 535, 411-415. [CrossRef]

14. Monaghan, A.J.; Bromwich, D.H.; Fogt, R.L.; Wang, S.H.; Mayewski, P.A.; Dixon, D.A.; Ekaykin, A.; Frezzotti, M.; Goodwin, I.; Isaksson, E.; et al. Insignificant change in Antarctic snowfall since the International Geophysical Year. Science 2006, 313, 827-831. [CrossRef] [PubMed]

15. Nicolas, J.P.; Bromwich, D.H. New Reconstruction of Antarctic Near-Surface Temperatures: Multidecadal Trends and Reliability of Global Reanalyses. J. Clim. 2014, 27, 8070-8093. [CrossRef]

16. Huai, B.; Wang, Y.; Ding, M.; Zhang, J.; Dong, X. An assessment of recent global atmospheric reanalyses for Antarctic near surface air temperature. Atmos. Res. 2019, 226, 181-191. [CrossRef]

17. Hodges, K.I.; Lee, R.W.; Bengtsson, L. A Comparison of Extratropical Cyclones in Recent Reanalyses ERA-Interim, NASA MERRA, NCEP CFSR, and JRA-25. J. Clim. 2011, 24, 4888-4906. [CrossRef]

18. Dee, D.P.; Uppala, S.M.; Simmons, A.J.; Berrisford, P.; Poli, P.; Kobayashi, S.; Andrae, U.; Balmaseda, M.A.; Balsamo, G.; Bauer, P.; et al. The ERA-Interim reanalysis: Configuration and performance of the data assimilation system. Q. J. R. Meteorol. Soc. 2011, 137, 553-597. [CrossRef]

19. Mooney, P.A.; Mulligan, F.J.; Fealy, R. Comparison of ERA-40, ERA-Interim and NCEP/NCAR reanalysis data with observed surface air temperatures over Ireland. Int. J. Climatol. 2011, 31, 545-557. [CrossRef]

20. Poveda, G.; Waylen, P.R.; Pulwarty, R.S. Annual and inter-annual variability of the present climate in northern South America and southern Mesoamerica. Paleogeogr. Paleoclimatol. Paleoecol. 2006, 234, 3-27. [CrossRef] 
21. Simmons, A.J.; Jones, P.D.; Bechtold, V.D.; Beljaars, A.C.M.; Kallberg, P.W.; Saarinen, S.; Uppala, S.M.; Viterbo, P.; Wedi, N. Comparison of trends and low-frequency variability in CRU, ERA-40, and NCEP/NCAR analyses of surface air temperature. J. Geophys. Res.-Atmos. 2004, 109, D24115. [CrossRef]

22. Zhu, J.; Xie, A.; Ding, M.; Zhao, C.; Guo, X.; Hu, W.; Xu, B.; Qin, X. Applicability analysis of the air temperature in the CMA Global ReAnalysis product CRA Interim in the section from Zhongshan Station to Dome A, East Antarctica. J. Glaciol. Geocryol. 2020, 42, 1145-1157.

23. Saha, S.; Moorthi, S.; Pan, H.L.; Wu, X.; Wang, J.; Nadiga, S.; Tripp, P.; Kistler, R.; Woollen, J.; Behringer, D.; et al. The NCEP Climate Forecast System Reanalysis. Bull. Amer. Meteor. Soc. 2010, 91, 1015-1057. [CrossRef]

24. Kobayashi, S.; Ota, Y.; Harada, Y.; Ebita, A.; Moriya, M.; Onoda, H.; Onogi, K.; Kamahori, H.; Kobayashi, C.; Endo, H.; et al. The JRA-55 Reanalysis: General Specifications and Basic Characteristics. J. Meteorol. Soc. Jpn. 2015, 93, 5-48. [CrossRef]

25. Xie, A.; Wang, S.; Xiao, C.; Kang, S.; Gong, J.; Ding, M.; Li, C.; Dou, T.; Ren, J.; Qin, D. Can temperature extremes in East Antarctica be replicated from ERA Interim reanalysis? Arct. Antarct. Alp. Res. 2016, 48, 603-621. [CrossRef]

26. Kim, H.G.; Kim, J.Y.; Kang, Y.H. Comparative Evaluation of the Third-Generation Reanalysis Data for Wind Resource Assessment of the Southwestern Offshore in South Korea. Atmosphere 2018, 9, 73.

27. Bao, X.; Zhang, F. Evaluation of NCEP-CFSR, NCEP-NCAR, ERA-Interim, and ERA-40 Reanalysis Datasets against Independent Sounding Observations over the Tibetan Plateau. J. Clim. 2013, 26, 206-214. [CrossRef]

28. Zhang, Y.; Wang, Y.; Huai, B.; Ding, M.; Sun, W. Skill of the two 20th century reanalyses in representing Antarctic near-surface air temperature. Int. J. Climatol. 2018, 38, 4225-4238. [CrossRef]

29. Jones, P.D.; Lister, D.H.; Osborn, T.J.; Harpham, C.; Salmon, M.; Morice, C.P. Hemispheric and large-scale land-surface air temperature variations: An extensive revision and an update to 2010. J. Geophys. Res.-Atmos. 2012, 117, D05127. [CrossRef]

30. Jones, P.D.; Harpham, C. Estimation of the absolute surface air temperature of the Earth. J. Geophys. Res.-Atmos. 2013, 118, 3213-3217. [CrossRef]

31. Jones, P.D.; Lister, D.H. Antarctic near-surface air temperatures compared with ERA-Interim values since 1979. Int. J. Climatol. 2015, 35, 1354-1366. [CrossRef]

32. Freville, H.; Brun, E.; Picard, G.; Tatarinova, N.; Arnaud, L.; Lanconelli, C.; Reijmer, C.; van den Broeke, M. Using MODIS land surface temperatures and the Crocus snow model to understand the warm bias of ERA-Interim reanalyses at the surface in Antarctica. Cryosphere 2014, 8, 1361-1373. [CrossRef]

33. Bracegirdle, T.J.; Marshall, G.J. The Reliability of Antarctic Tropospheric Pressure and Temperature in the Latest Global Reanalyses. J. Clim. 2012, 25, 7138-7146. [CrossRef]

34. Tetzner, D.; Thomas, E.; Allen, C. A Validation of ERA5 Reanalysis Data in the Southern Antarctic Peninsula-Ellsworth Land Region, and Its Implications for Ice Core Studies. Geosciences 2019, 9, 289. [CrossRef]

35. Lazzara, M.A.; Weidner, G.A.; Keller, L.M.; Thom, J.E.; Cassano, J.J. Antarctic Automatic Weather Station Program 30 Years of Polar Observations. Bull. Amer. Meteorol. Soc. 2012, 93, 1519-1537. [CrossRef]

36. Turner, J.; Colwell, S.R.; Marshall, G.J.; Lachlan-Cope, T.A.; Carleton, A.M.; Jones, P.D.; Lagun, V.; Reid, P.A.; Iagovkina, S. The SCAR READER project: Toward a high-quality database of mean Antarctic meteorological observations. J. Clim. 2004, 17, 2890-2898. [CrossRef]

37. Station Surface Data. Available online: https://legacy.bas.ac.uk/met/READER/surface (accessed on 2 February 2021).

38. Available online: http://www.add.scar.org/index.jsp (accessed on 2 February 2021).

39. Olauson, J. ERA5: The new champion of wind power modelling? Renew. Energy 2018, 126, 322-331. [CrossRef]

40. Urraca, R.; Huld, T.; Gracia-Amillo, A.; Javier Martinez-de-Pison, F.; Kaspar, F.; Sanz-Garcia, A. Evaluation of global horizontal irradiance estimates from ERA5 and COSMO-REA6 reanalyses using ground and satellite-based data. Sol. Energy 2018, 164, 339-354. [CrossRef]

41. Available online: https://cds.climate.copernicus.eu/\#!/search?text=ERA5\&type=dataset (accessed on 2 February 2021).

42. Available online: https://apps.ecmwf.int/datasets/data/interim-full-daily/levtype=sfc/ (accessed on 2 February 2021).

43. Xie, A.; Allison, I.; Xiao, C.; Wang, S.; Ren, J.; Qin, D. Assessment of air temperatures from different meteorological reanalyses for the East Antarctic region between Zhongshan and Dome A. Sci. China-Earth Sci. 2014, 57, 1538-1550. [CrossRef]

44. Connolley, W.M. The Antarctic temperature inversion. Int. J. Climatol. 1996, 16, 1333-1342. [CrossRef]

45. van de Berg, W.J.; van den Broeke, M.R.; van Meijgaard, E. Heat budget of the East Antarctic lower atmosphere derived from a regional atmospheric climate model. J. Geophys. Res.-Atmos. 2007, 112, D23101. [CrossRef]

46. Genthon, C.; Six, D.; Favier, V.; Lazzara, M.; Keller, L. Atmospheric Temperature Measurement Biases on the Antarctic Plateau. J. Atmos. Ocean. Technol. 2011, 28, 1598-1605. [CrossRef]

47. Bromwich, D.H.; Nicolas, J.P.; Hines, K.M.; Kay, J.E.; Key, E.L.; Lazzara, M.A.; Lubin, D.; McFarquhar, G.M.; Gorodetskaya, I.V.; Grosvenor, D.P.; et al. Tropospheric clouds in Antarctica. Rev. Geophys. 2012, 50, RG1004. [CrossRef]

48. Stammerjohn, S.E.; Martinson, D.G.; Smith, R.C.; Yuan, X.; Rind, D. Trends in Antarctic annual sea ice retreat and advance and their relation to El Nino-Southern Oscillation and Southern Annular Mode variability. J. Geophys. Res.-Oceans 2008, 113, C03S90. [CrossRef]

49. Oliva, M.; Navarro, F.; Hrbacek, F.; Hernandez, A.; Nyvlt, D.; Pereira, P.; Ruiz-Fernandez, J.; Trigo, R. Recent regional climate cooling on the Antarctic Peninsula and associated impacts on the cryosphere. Sci. Total Environ. 2017, 580, 210-223. [CrossRef] 
50. Ding, Q.; Steig, E.J.; Battisti, D.S.; Kuettel, M. Winter warming in West Antarctica caused by central tropical Pacific warming. Nat. Geosci. 2011, 4, 398-403. [CrossRef]

51. Marshall, G.J.; Orr, A.; Turner, J. A Predominant Reversal in the Relationship between the SAM and East Antarctic Temperatures during the Twenty-First Century. J. Clim. 2013, 26, 5196-5204. [CrossRef]

52. Turner, J.; Comiso, J.C.; Marshall, G.J.; Lachlan-Cope, T.A.; Bracegirdle, T.; Maksym, T.; Meredith, M.P.; Wang, Z.; Orr, A Non-annular atmospheric circulation change induced by stratospheric ozone depletion and its role in the recent increase of Antarctic sea ice extent. Geophys. Res. Lett. 2009, 36, L08502. [CrossRef]

53. Chapman, W.L.; Walsh, J.E. A synthesis of Antarctic temperatures. J. Clim. 2007, 20, 4096-4117. [CrossRef]

54. Monaghan, A.J.; Bromwich, D.H.; Chapman, W.; Comiso, J.C. Recent variability and trends of Antarctic near-surface temperature. J. Geophys. Res.-Atmos. 2008, 113, D04105. [CrossRef] 